\title{
Assessment of perceived labor market conditions in employees' turnover intention model - mediation and moderation analyzes
}

\author{
Mohd Abass Bhat \\ Department of Business Studies, University of Technology and Applied Sciences, \\ Muscat, Oman \\ Shagufta Tariq Khan \\ Department of Accounting, Faculty of Business Administration, Jazan University, \\ Jazan, Saudi Arabia, and \\ Riyaz Ahmad Rainayee \\ Department of Commerce, University of Kashmir, Srinagar, India
}

\begin{abstract}
Purpose - This paper aims to examine employee perceptions of the labor market in the employee turnover intention model and explores how different situations outside work (labor market conditions) play a role in employee-organizational membership. In addition, it also examines the mediating role of commitment in the relationship between stress and the turnover model.

Design/methodology/approach - Data were collected from 628 private school teachers working in the economically depressed state of $\mathrm{J} \& \mathrm{~K}$ (India), which were randomly selected. Confirmatory factor analysis was used for validation of a scale. Structural equation modeling and PROCESS by Hayes was used to test the hypothesized relationships between the study variables.

Findings - The antecedents of occupational stressors contribute negatively toward employees' psychological state resulting in undesirable employee-organizational relationships such as high turnover intentions and low organizational commitment. Nevertheless, lack of external job opportunities compels employees to maintain organizational membership, even though against the stressful working environment.

Research limitations/implications - This study while acknowledging the inherent limitations, questionnaires are susceptible to and single sectional nature of the study poses limitations.

Practical implications - The practical implication explains that the employee and organization relationship is governed more by external economic conditions than by the psychological feelings of the employees toward the organization (organizational commitment). As also, the moral system of employees, as well as their feelings toward the noble profession makes them feel morally exalted and this binds them to the membership of the organization.

Originality/value - This study mainly focuses on, to understand if and how the conditions of the labor market relate to the employees' attitudes. This would enable us to gain more insights to the systematic

(C) Mohd Abass Bhat, Shagufta Tariq and Riyaz Ahmad Rainayee. Published in PSU Research Review. Published by Emerald Publishing Limited. This article is published under the Creative Commons Attribution (CC BY 4.0) licence. Anyone may reproduce, distribute, translate and create derivative works of this article (for both commercial and non-commercial purposes), subject to full attribution to the original publication and authors. The full terms of this licence maybe seen at http:// creativecommons.org/licences/by/4.0/legalcode
\end{abstract}

Received 30 May 2020 Revised 23 August 2020 Accepted 16 September 2020 
relations of employees' attitudinal variables such as occupational stress, organizational commitment and employee turnover intentions.

Keywords Organizational commitment, Occupational stress, Employees' turnover intentions model, Mediation and moderation, Perceived labor market conditions

Paper type Research paper

\section{Introduction}

To survive in the cut-throat business competition, employers emphasize cost reduction to increase the input-output ratio as a major strategic tool (Hobfoll et al., 2018). For that matter, more often than not, they take beneficial leverage of poor external labor market conditions by paying low wages to their employees and employ an inadequate workforce in their business organizations. It, consequently, results in undue work pressure on employees at their workplaces (Menon and Priya, 2019). Cosmos Institution of Mental Health and Behavioral Sciences (CIMBS, 2019) reports a rise in depression and anxiety-related conditions, the largest provider of workplace support services to businesses, stress-related grievances from workers rose from the previous year to $16 \%$ in 2019. More convincingly, it could be asserted that economic slowdown meshed with competition are forcing organizations to improve productivity and consequently crystallize on employees' increased job pressure may result in job stress (Geetha Nema et al., 2010). In most of the cases, professionals were concerned about the financial risk, job loss, loss of business or financial uncertainty that caused the anxiety disorder. In a few instances, financial loss and subsequent stress triggered even suicidal behavior (Manier et al., 2017). In other words, in an attempt to maximize profits, some organizations have resorted to unlawful business practices like "casualization" of workers that harshly hurts workers' interests and violates some fundamental labor laws (Okafor, 2007). In response, employees are not only expected to work longer than they did earlier but are also expected to meet work deadlines, which puts immense pressure to perform more in a shorter time. Stephen and Timothy (2007) and Geetha et al. (2010) observed that in economic slowdown, business organizations are fighting for survival that causes survival problems for employees within organizations. Two major effects that have stemmed from these economic changes are known as "work intensification" and "job insecurity." The former refers to the extent to which employees are being forced to work faster and harder, while the latter refers to the subjective feelings about the risk of job loss, as expressed by employees themselves (Burchell et al., 2002). On the other hand, the larger alternate employment opportunities lead employees to analyze cost and benefit and have intentions to switch jobs (Price, 2001). As such, employees receive offers from other employers and make a comparison of cost and benefit between current and alternate jobs (Price, 2001). Nevertheless, if there are no alternate employment options available, employees recalibrate their expectations about their current job in the light of the feasibility of finding alternate jobs. Employees may depart psychologically without actually resigning, withdraw their decision to participate (Rousseau, 2004). Thus, there is a reduction in the discretionary efforts of employees (Hom et al., 2012). Aaron and Ronit (2007) argue that behaviors are often influenced by economic conditions that cannot be controlled by the investigator but can influence the findings. Further, Manu et al. (2004) also maintain that employees quit organizations due to economic reasons.

Therefore, in times of high unemployment rates, employees are less likely to express high turnover rates (Onyishi et al., 2012; Dello Russo et al., 2020). The result is "casualization" and undesirable working conditions as antecedents of the adverse economic conditions (Kazeem, 2004). As such, employees who seek to leave, but perceive few job alternates (reluctant stayers) experience a shock. The possible interaction effect between 
perceiving few alternate employment opportunities and job stress can be well-understood by referring to the job demand resources model (Bakker, 2001; Demerouti et al., 2001). According to the job demand resources model, job demands refer to those aspects of the job that are perceived burdensome by the employees (e.g. occupational stress). While as, resources can provide a way toward improving control, commitment, personal growth, learning and development (Demerouti et al., 2001; Hakanen et al., 2005). A core assumption of the job demand resources model is that resources are something that can prevent unfavorable effects of demands. Further, employees can better control their working life because of alternate employment opportunities (Berntson and Marklund, 2006). Similar understanding is based on Karasek's job demand control model (Lewchuk et al., 2005; Cooper, 2002) that exposes employees' experience high demands with low control results in their occupational stress. This interaction is highly determined by perceived labor market conditions (PLMC) and not by the job itself. In accordance with this model, job stress involving high demands and perceiving less alternate employment opportunities resist actual turnover behavior (Silla et al., 2009). As employees perceive less employment opportunities accompanied by low sense of control, their ability to find secure employment seems limited.

In this background, we seek to establish the moderating role of labor market conditions perceived by the employees (working in an economically depressed state) in the relationship between employees' occupational stress and employees' turnover intentions. When alternate jobs are scarce, employees are more likely to involve less in actual departure. The rationale here is that PLMC may be the variable that is likely to influence or strengthen the direction of the relationship. To further strengthen our assertion, the implication of unemployment has clearly demonstrated and widely acknowledged to have a large influence in particular associated with a strong negative impact on measures of life satisfaction (Waters, 2000). The empirical findings also show unemployed have higher levels of perceived stress (Meer, 2014). We believe that employees in times of adverse labor market conditions hold their membership with their organizations even being highly stressed. Thus, alternate job options are, therefore, an intermediate stage between work dissatisfaction and turnover, which have a direct and indirect effect on the decision to leave because of job dissatisfaction affected by the general labor market (Chan and Darian Ao, 2019). This, in turn, is psychologically and scientifically believed to crystallize into perceived financial insecurity, and becomes a major catalyst of occupational stress. It could possibly also result in poor perceived administrative support and may psychologically create a negative feeling among the employees toward their organizations. This may have a significant overall negative impact on the employees' well-being at the workplace in today's marketplace and may even prove to be fatal (Geetha et al., 2010).

Furthermore, with the changing socio-economic scenario and increasing unemployment rate at $8.4 \%$ according to the Center for Monitoring Indian Economy, the Indian Government and research from the Reserve Bank of India, which demonstrate higher in past 45-year high. The value of employees and their professional concerns associated with the job have undergone a change (Biglan and Embry, 2013) resulting in an increasing level of stress and hassle among the employees, as these stressful employees can no longer contribute toward the achievement of the organizational goals. However, little is known about how economic opportunity influences employees' turnover. It questions about the universality of turnover intention models. As most of the research studies in the subject matter of turnover intentions are mostly related to the organizational commitment and occupational stress. However, the inclusion of the perceived external opportunities variable as the moderator in turnover intention models has never been studied. In this backdrop, to clear the relationship among stress, commitment, turnover intention and PLMC, stress turnover has been introduced as a moderator between these variables. Further, commitment as a mediator in 
the relationship between stress and turnover intention has also been assessed. Compounding the issue, J\&K State (India) has witnessed 194\% increase in the number of job seekers registering themselves with government employment exchanges, over the past five years. In the economic report for the year 2016, the J\&K Government had stated that $24.6 \%$ of the state's population in the age group of 18-29 years as unemployed against all India rate of $13.2 \%$ for this group. Further, it is reported that the figures may go up as all the unemployed persons do not register themselves. However, an employer exploits the vast pool and taking the leverage of prevailing conditions in the state of a depressed economy where the unemployment rate is high (Ahmad, 2018). It puts compulsion upon employees to remain within their organizations, even in adverse conditions irrespective of their choice. In this very background, the study of perceived external opportunities in relation to turnover intentions becomes imperative and interesting.

\section{Review of literature and formation of research hypotheses}

Turnover intention as an employee's cognitive response to the working conditions of a particular organization and to the economic condition of a nation as a whole, which stimulates an employee to search for better alternate jobs and consequently voluntarily intent to leave an organization (Ahmad and Rainayee, 2013). Goading on this perspective of employee turnover intention concept, it may be asserted that an employee turnover intention is the function of organizational and the economic conditions of the nation. Thus, an attempt of determining the implication of labor market conditions in the contemporary employee turnover intention models are initiated in the present study. On the spur of the moment, we find that researchers have come up with diverse antecedents of employee turnover intentions. These antecedents include job-related organizational and economic factors. An in-depth literature review revealed that employee turnover intention has been studied with employee repulsive psychological variables such as occupational stress and with affective employee attitude such as organizational commitment. Therefore, we review the numerous employee turnover intention models.

In fact, considering the theoretical base, contemporary turnover models, more often include both stress and commitment as determinants that initiate the turnover process. We classified these models into four categories, namely, models demonstrating the relationship between occupational stress and turnover intentions, models pertaining to organizational commitment and employee turnover intentions, models, which incorporate occupational stress, organizational commitment and turnover intentions and comprehensive models incorporating occupational stress, organizational commitment, turnover intentions and PLMC being studied from a broader perspective.

\section{Stress and turnover intention}

Stress theories illustrate individuals' reactions to stressors are partly dependent on individuals' cognitive appraisals of the potential stressors (Robinson, 2018). This is particularly true when predicting outcomes such as employee turnover intention. Stress has been extensively researched as a result of the negative effects that it can have on people, organizations and communities (Harter et al., 2002; Kim and Stoner, 2008; Kim and Lee, 2009; Horton and O'Fallon, 2011; Tiyce et al., 2013; Kafashpoor et al., 2014; Han et al., 2015; Kim et al., 2016; Montani et al., 2017; Mérida-López and Extremera, 2017; Karatepe et al., 2018; Huang et al., 2018; Nilufer, 2019). Studies have sought to address the issue of what defines the desire of employees to leave by examining potential antecedents of the decisions of the employees to leave. The research demonstrates that there is a constructive impact of stress on turnover expectations, as has definitely been shown by other academicians (Kim and Stoner, 2008; 
Kim and Lee, 2009; Kim et al., 2016) and they highlight that stress correlates with job dissatisfaction, absenteeism and turnover (Magnano et al., 2017; Mérida-López and Extremera, 2017). Occupational stress is a significant antecedent of the attrition of workers (Bedeian and Armenakis, 1981; Fogarty et al., 2000; Han et al., 2015; Kim and Stoner, 2008). Furthermore, as an administrator pushes employees toward more technological devices to boost workplace efficiency as a workaround that puts him under techno-stress (Hossain et al., 2019a). This high job pressure and heavy schedule may theoretically generate occupational stress (Kafashpoor et al., 2014). Based on the literature reviewed and results obtained, the authors conclude that the hypothesis of this study describes the relation between occupational stress and turnover intention:

\section{H1. Occupational stress leads to employee's intention to leave their organization.}

\section{Stress and commitment}

Occupational stress refers to an employee's response to characteristics that appear to be mentally and physically challenging at work (Bhat, 2013). The physical and psychological health can degrade as workers are stressed. In fact, psychiatric manifestations of fear, depression and anger have a direct effect on workplace stress and also can contribute to burnout and reduce organizational commitment (Wong and Spence, 2015; Lu et al., 2017; Huang et al., 2018). Retention model and findings from previous studies (Lu et al., 2017; Wong and Spence, 2015) describe occupational stress as an intermediate variable that directly affects the employee's willingness to leave (Cooke et al., 2007; Mulki et al., 2008). It was also found that to whatever extent workers are suffering from occupational stress, the same amount of low organizational commitment of employees will result in unproductive outcomes (Kafashpoor et al., 2014; Khuong and Nhu, 2015). Therefore, it is hypothesized:

H2. There is a negative relationship between occupational stress and organizational commitment.

\section{Commitment and turnover intention}

Organizational commitment is a psychological connection between employees and their employer to create their employee with belief in organizational objectives and values to ensure the employees do not have an intention to leave their jobs (Meyer and Allen, 1997; Schmidt, 2007; Kumar, 2012; Van der Westhuizen, 2014; Haque and Yamoah, 2014; Han et al., 2015; Haque and Aston, 2016; Haque et al., 2016; Chiang and Liu, 2017). Prior studies reported three forms of organizational commitment (affective, normative and continuance) that have a significant negative association with turnover intentions (Meyer and Allen, 1997; Hashemi et al., 2015; Nair and Kamalanabhan, 2010; Mosadeghrad, 2013). Of these, affective organizational commitment represents the emotional and attitudinal attachment to an employer organization (Mercurio, 2015; Tetteh et al., 2019). Whilst normative and continuance involve a sense of obligation and costavoidance, respectively (Meyer and Herscovitch, 2001; Snape and Redman, 2003). More importantly, employees who are attached with the organization may consider themselves as being part of a "family," which may reduce their exit intention (Fazio et al., 2017; Marique and Stinglhamber, 2011; Meyer et al., 2002). Consequently, employees with high levels of commitment may have a stronger desire to remain in their organizations and do not opt for turnover. Therefore, the literature on employee turnover intentions as antecedents of organizational commitment provides a clear conceptual association between these variables. As such, a negative 
relationship between employee turnover intentions and organizational commitment has been consistently reported by the numerous studies based on what we hypothesize:

H3. There is a negative relationship between organizational commitment and employee turnover intentions

\section{Stress, commitment and turnover intention}

Behavioral scientists around the globe have systematically demonstrated a positive relationship between employee turnover intention and stress. Earlier, Mikkelsen et al. (2000) and Bhat (2019) found that employees who have high level of stress are less committed. The empirical results also show organizational commitment has a major impact on turnover intention. Azar (2014) found that affective and continuous commitments were positively and negatively related to job stress. In other words, to whatever the extent a person suffers from job stress, the same amount of affective commitment he or she exhibits. Aydem (2011) posits that employees' psychological imbalance spurs from the context of their job, which demises their emotional attachment toward their organization. Smith (2009) assessed the plausibility of three alternate model specifications of the relations between role stressors and organizational commitment, satisfaction, turnover intentions and reported the best fit for their "fully mediated effects" model wherein there was a "strong causal path from stress, satisfaction, commitment and intentions to leave." Ramamoorthy and Flood (2004) found that commitment mediates the relationship between organizational justice and turnover intention. Moreover, a study by Nilufer (2019) shows the results of the regression analysis that indicated the job stress affected the turnover intention in a positive way, while the organizational commitment affected it in a negative way. The results also indicated that organizational commitment seemed to have a partial mediating role on the relationship between job stress and turnover intention. It is also expected that a commitment has an affective attitudinal role to act as a mediator between competitive psychological climate and turnover intention. Based on the belief-attitude-behavioral intention model (Fishbein and Ajzen, 1975), attitude is posited to mediate the relationship between belief and behavioral intention. Therefore, it is hypothesized:

H4. Organizational commitment mediates the relationship between occupational stress and employees' turnover intentions.

\section{Moderating role of perceived labor market conditions}

Owing to the inconsistency in the relationship of organizational commitment and occupational stress with respect to PLMC of retention-related criteria we hypothesize moderating role of PLMC in the employee turnover intention model. PLMC refers to the understanding of an employee about the availability of alternate jobs in the external environment (Ahmad et al., 2019). Employees perceive better alternate job opportunities when the job market is at prosperity compared to the state of unemployment. It should be noted, however, that PLMC is not the same thing as actual labor market conditions. Hossain et al. (2020a) found that tight labor market conditions are encouraging unemployed women, in specific, to use smartphones to start their own setups, particularly in the subcontinent. Today, social networking (Hossain et al. 2020b) and innovative ideas help to build venture creation, which generate additional economic opportunities for people with low income in the society (Hossain et al., 2020c). Moreover, sustainable development in education would also assist to create better economic prospects (Hossain et al., 2019b). Past research suggests 
that if organizations fail to provide substantial growth opportunities, employees actively start searching for an alternate job and their search is based upon the perceived opportunities in the external market (Mano-Negrin and Tzafrir, 2004). However, it is theorized that individuals will not leave their jobs without employment alternates available (Ahmad et al., 2019).

Therefore, determinants influence flow through economic opportunity, potentially moderating the relationship between determinants and turnover. In reality, when evaluating alternate jobs, individuals perform cost/benefit analysis (Boswell, 2017). In an extended model, withdrawal behaviors were influenced by workplace expectations and perceptions of the labor market (Zimmerman et al., 2016). On the basis of the theoretical work provided by Muchinsky and Morrow (1980) and Carsten and Spector (1987), who conducted a metaanalysis to examine how the magnitude of the relationship between employees' positive attitude and turnover varied during high and low unemployment rates. They found a correlation that ranged from low to moderate between unemployment rates and the strength of the satisfaction-turnover relationships, suggesting that the satisfaction-turnover relationship is moderated by economic opportunity. Economic opportunities and perceived alternates are central constructs in volunteer turnover models, which reflect conceptualizations of job availability at different levels (Shaw and Hausknecht, 2017). While perceived alternates represent an employee's perceptions of the labor market, economic opportunity refers to more objective conditions of the labor market. Carsten and Spector (1987) also found a correlation that ranged from low to moderate $(-0.18$ to -0.52$)$ between unemployment rates and the strength of the employee attitude-turnover relationships, suggesting that this relationship is moderated by economic opportunity. Therefore, in explaining the magnitude of the variance explained, authors have included some external forces in the formation of employees' unique psychology toward their organization exhibited at the workplace, owing to which, number of authors have machinated the model with the inclusion of employee perception toward the labor market conditions. Thus, based on many existing studies and theories that have been described above, researchers deciphered that job stress has a negative effect on the turnover intention of employees and of course the presence of the stress may affect the willingness of employees to leave the organization and explore alternate jobs. In the light of the above discussion, the following hypotheses have been proposed:

H5. PLMC moderates the relationship between occupational stress and turnover intention, so that the positive relationship between occupational stress and turnover intention is stronger under the condition of high versus low PLMC $(H 5 a)$ and so that the negative relationship between occupational stress and organizational commitment is weaker under the condition of high versus low $\operatorname{PLMC}(H 5 b)$.

\section{Research gaps}

Some theoretical employees' turnover models (Cha, 2008) have included economic incentives and some other studies have found variables closely linked to PLMC such as employment security (Silla et al., 2009) and chances of getting a new job (Heit et al., 2000), but its moderating effects are not typically examined in employee's turnover models (Collins et al., 2013). This study mainly focuses on to understand if and how the conditions of the labor market relate to the employees' attitudes. This would enable us to gain more insights to the systematic relations among employees' attitudinal variables such as occupational stress, organizational commitment and employees' turnover intentions. Although available 
literature provides enough credence with regard to the relationship between employees' turnover intentions, occupational stress and organizational commitment, however, the nature of the relationship between turnover intentions, stress and commitment does not demonstrate a clear picture. As such, some behavioral scientists systematically assert a positive association between stress and commitment, while others claim a negative relationship. Thus, the present study intends to focus broadly on the role of employees' PLMC in the conventional model of employees' turnover intentions. This paper incorporates employees' perception toward the labor market in employees' turnover intention models and investigates how various situations outside work (labor market conditions) play a role in the employee-organization membership.

\section{Proposed research model}

The model of the study has been developed based on the review of the literature and existing research gaps shown in Figure 1, which identified occupational stress and organizational commitment as independent variables and turnover intentions as a dependent variable. In addition, the model contains PLMC, which acts as a moderator and influences the strength of the relationship between occupational stress and employee turnover intentions; organizational commitment and employee turnover intentions.

\section{Methodology}

\section{Generation of scale items}

The methodology adopted for the validation and generation of scale has been recommended by Churchill (1979), Anderson and Gerbing (1988); Saxe and Barton (1982), Hair et al. (2006); and Malhotra and Dash (2011). The occupational stress construct has been studied together with other three constructs i.e. organizational commitment, PLMC and turnover intentions. Instruments were developed after in-depth discussions with the respondents with regard to the stress causing problems they faced in the schools. These problems were identified and converted into statements. After matching these statements with existing literature some factors were also supported by the existing literature. As a sequel, seven most relevant antecedents were identified and then subjected to content validity where experts' opinions were sought. In the end, these statements were retained in the questionnaire and were measured with 29 items comprising of 5 items each for poor administrative support (PAS), employees' exploitation, work overload and 4 items for professional distress and inadequate financial security each and 3 items for job insecurity and strenuous working environment each. The research studies of Cox (1987), Kyriacou and Sutcliffe (1977); Srivastava and Singh (1984),

Figure 1. Proposed research model

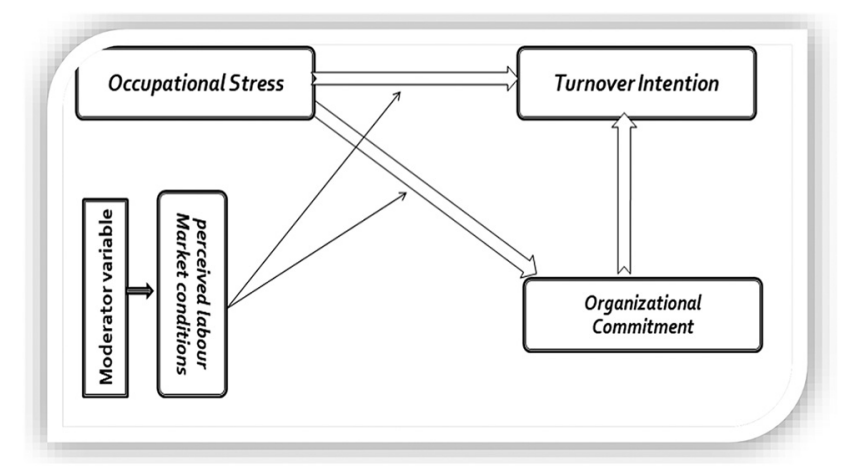


Cartwright and Cooper (2002), Nixon et al. (2011); Towers Watson Survey (2014) were consulted for generating items. PLMC variable was measured by one-dimensional scale consisting of five items that was adopted from Mowday et al. (1984), Billings and Wemmerus (1983); Arnold and Feldman (1982), Michaels and Spector (1982); Hurrell and McLaney (1988) and Williams and Cooper (1998). While as turnover intentions construct was administered by single-dimensional scale of three items used in previous studies of Cummann et al. (1979); Becker and Billings (1993); O'Driscoll and Beehr's (1994); Nissly et al. (2005). Finally, the multidimensional organizational commitment scale, which comprises of six items each for affective commitment, continuance commitment, normative commitment was used (Meyer and Allen, 1991; Karrasch, 2003). Some items were kept in negative form so as to have an internal cross-checking and to ensure the active involvement of respondents while filling the questionnaire. All the items and variables along with operationalization are given in Appendix.

\section{Pre-testing of the instrument}

The pilot test pertains to the administration of the survey instrument to a set of small number of respondents. Its main purpose is to ensure the general feasibility of the data collection method, specifically to assess the validity and reliability of the research instrument. The pilot study was conducted on a sample of 128 respondents in April 2019 in line with the procedure laid down by Chahal and Kaur (2014) to validate the concepts under study. The respondents from whom data were collected should have at least one year of experience as school teachers. During the test, 56 items were initially drafted. All the items were thoroughly explained to respondents. Furthermore, the opinion of respondents was considered for further refinement of the questionnaire. All responses were recorded on a five point-Likert scale, ranging from 5 for strongly agree to 1 for strongly disagree. The collected data were subjected to instrument purification through item analysis as mentioned in the next section.

\section{Item analysis}

To develop item analysis and validate measures for various constructs, scale development procedures were used. Some interrelated statistical techniques were used to analyze data and support our models. Item analysis is a set of measures that analyzes responses of each item to determine, which items best determine the construct. It is used to review the quality of individual test items and overall instrument (Netmeyer et al., 2003). Therefore, item analysis was performed with confirmatory factory analysis (CFA), reliability analysis and validity analysis. CFA using item loadings should be statistically significant and higher than 0.5, ideally higher than 0.70 (Hair et al., 2006) and relevant fit indices, such as chi-square statistic, root mean square error of approximation (RMSEA), goodness of fit index (GFI) and comparative fit index (CFI) as mentioned in footnotes corresponding to Figures $2-5$. This methodology is used following the recommendations of Churchill (1979), Anderson and Gerbing (1988); Malhotra and Dash (2011); Saxe and Barton (1982) and Hair et al. (2006). The reliability of each construct of the study has been analyzed based on the criteria that include Cronbach's alpha that should be greater than 0.70 Hair et al. (2006). The item-total correlation was also estimated and items with high item-total correlation have more variance relating to what the items have in common (Nunnally and Bernstein, 1994). Items with item-total correlation more than or equal to 0.35 were retained and the rest were deleted (Saxe and Barton, 1982).

CFA has been used to test whether items in the construct stand at 0.5 or higher, and ideally equal to 0.70 are considered significant factors loadings. Average variance extracted 
PRR

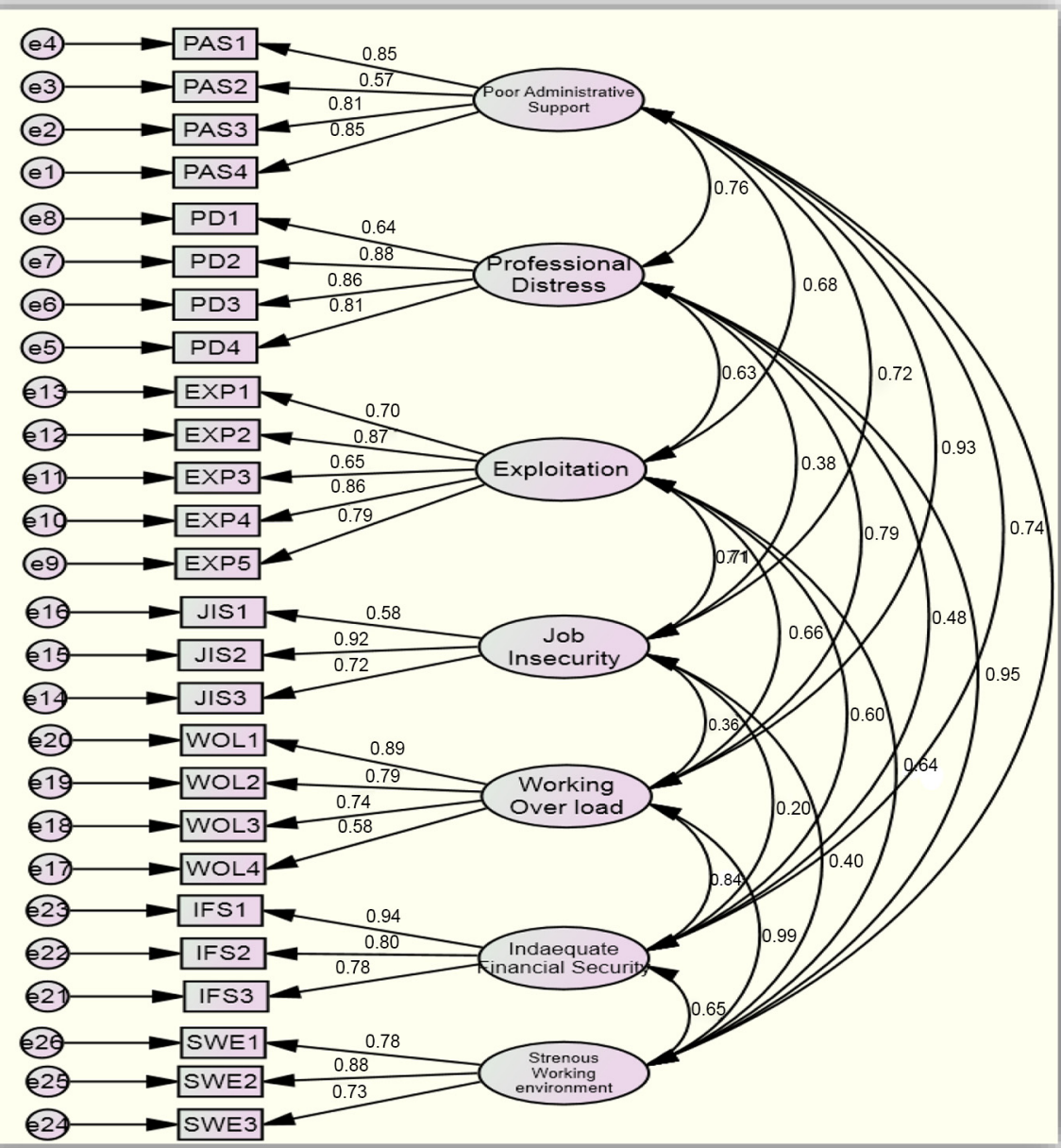

Figure 2.

Measurement model of occupational stress
Notes: Key: PAS1-PAS4 are the manifest variables of Poor Administrative Support; PD1-PD3 are the manifest variables of Professional Distress; Exp1-Exp5 are the manifest variables of Exploitation; JIS1-JIS3 are the manifest variables of Job Insecurity; WOL1-WOL3 are the manifest variables of work overload; IFS1-IFS3 are the manifest variables of Inadequate Financial Security; SWE1-SWE3 are the manifest variables of Strenuous Working Environment and e1-e26 are the error terms of manifest variables

(AVE) should be 0.5 or greater to establish adequate convergent validity. Construct reliability (CR) should be 0.7 or higher to indicate adequate convergence or internal consistency and for discriminant validity (DV), the square of the correlation between factors should not exceed the variance extracted (Fornell and Larcker, 1981). Tables 1-3 reveal that all items have higher factor loadings, except one item for "inadequate financial security" and "normative commitment" each, which had standardized factor loadings owing to which it 


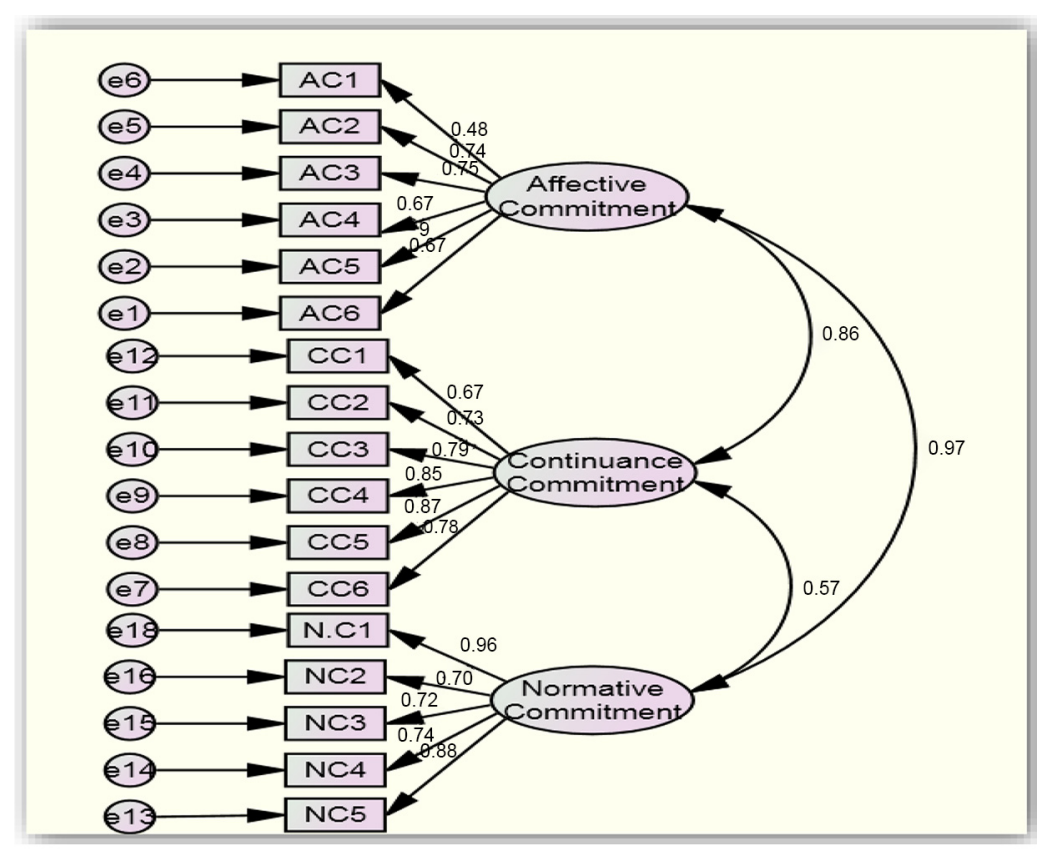

Labor market conditions

Notes: Key: AC1-AC6 are the manifest variables of Affective Commitment; $\mathrm{CC} 1-\mathrm{CC} 5$ are the manifest variables of Continuance Commitment; NC1-NC6 are the manifest variables of Normative Commitment; and e1-e17 are the error terms of manifest variables

Figure 3.

Measurement model of organizational commitment

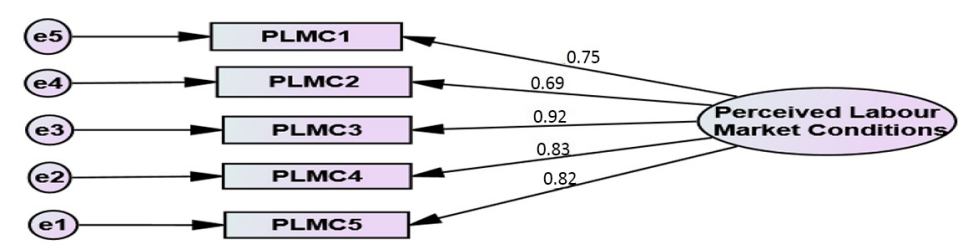

Note: Key: PEO1-PEO5 = perceived labor market conditions and el-e5 are the error terms of manifest variables

Figure 4. Measurement model of perceived labor market conditions

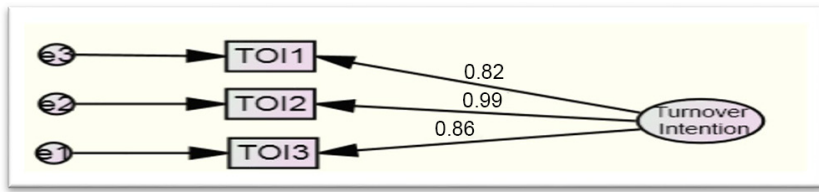

Note: Key: TOI1-TOI3 = turnover intention and e1-e3 are the error terms of manifest variables

Figure 5. Measurement model of turnover intention 


\section{PRR}

\begin{tabular}{|c|c|c|c|c|c|c|c|c|c|c|}
\hline $\begin{array}{l}\text { Item-total } \\
\text { correlation } \\
\text { Poor } \\
\text { administrative } \\
\text { support }\end{array}$ & $\begin{array}{l}\text { Item } \\
\text { label }\end{array}$ & PAS1 & PAS2 & PAS3 & PAS4 & & $\begin{array}{l}\text { Path } \\
\text { estimate }\end{array}$ & AVE & $\mathrm{CR}$ & $\begin{array}{c}\text { Cronbach's } \\
\text { alpha }\end{array}$ \\
\hline 0.573 & PAS1 & 1 & & & & & 0.85 & 0.560 & 0.833 & 0.828 \\
\hline 0.642 & PAS2 & 0.525 & 1 & & & & 0.57 & & & \\
\hline 0.735 & PAS3 & 0.583 & 0.487 & 1 & & & 0.81 & & & \\
\hline 0.684 & PAS4 & 0.361 & 0.617 & 0.721 & 1 & & 0.85 & & & \\
\hline $\begin{array}{l}\text { Professional } \\
\text { distress }\end{array}$ & $\begin{array}{l}\text { Item } \\
\text { label }\end{array}$ & PD1 & PD2 & PD3 & $\mathrm{PD} 4$ & & & 0.637 & 0.875 & 0.850 \\
\hline 0.687 & PD1 & 1 & & & & & 0.64 & & & \\
\hline 0.699 & PD2 & 0.481 & 1 & & & & 0.88 & & & \\
\hline 0.662 & PD3 & 0.467 & 0.753 & 1 & & & 0.86 & & & \\
\hline 0.723 & PD4 & 0.810 & 0.531 & 0.504 & 1 & & 0.81 & & & \\
\hline $\begin{array}{l}\text { Perceived } \\
\text { exploitation }\end{array}$ & $\begin{array}{l}\text { Item } \\
\text { label }\end{array}$ & PExp1 & PExp2 & PExp3 & PExp4 & PExp5 & & 0.602 & 0.882 & 0.877 \\
\hline 0.609 & PExp1 & 1 & & & & & 0.70 & & & \\
\hline 0.769 & PExp2 & 0.569 & 1 & & & & 0.87 & & & \\
\hline 0.571 & PExp3 & 0.528 & 0.517 & 1 & & & 0.65 & & & \\
\hline 0.829 & PExp4 & 0.482 & 0.742 & 0.742 & 1 & & 0.86 & & & \\
\hline 0.756 & PExp5 & 0.702 & 0.700 & 0.399 & 0.697 & 1 & 0.79 & & & \\
\hline Job insecurity & $\begin{array}{l}\text { Item } \\
\text { label }\end{array}$ & JIS1 & JIS2 & JIS3 & & & & 0.560 & 0.743 & 0.832 \\
\hline 0.748 & JIS1 & 1 & & & & & 0.58 & & & \\
\hline 0.604 & JIS2 & 0.575 & 1 & & & & 0.92 & & & \\
\hline 0.739 & JIS3 & 0.764 & 0.559 & 1 & & & 0.72 & & & \\
\hline $\begin{array}{l}\text { Work over } \\
\text { load }\end{array}$ & WOL1 & WOL2 & WOL3 & WOL4 & & & & 0.571 & 0.839 & 0.849 \\
\hline 0.700 & WOL1 & 1 & & & & & 0.89 & & & \\
\hline 0.656 & WOL2 & 0.642 & 1 & & & & 0.79 & & & \\
\hline 0.806 & WOL3 & 0.624 & 0.679 & 1 & & & 0.74 & & & \\
\hline 0.626 & WOL4 & 0.535 & 0.406 & 0.684 & 1 & & 0.58 & & & \\
\hline $\begin{array}{l}\text { Inadequate } \\
\text { financial } \\
\text { security }\end{array}$ & IFS1 & IFS2 & IFS3 & IFS4 & & & & 0.705 & 0.878 & 0.887 \\
\hline 0.779 & IFS1 & 1 & & & & & 0.94 & & & \\
\hline 0.789 & IFS2 & 0.735 & 1 & & & & 0.80 & & & \\
\hline 0.772 & IFS3 & 0.713 & 0.726 & 1 & & & 0.78 & & & \\
\hline 0.431 & IFS4 & 0.390 & 0.531 & 0.410 & 1 & & & & & \\
\hline $\begin{array}{l}\text { Strenuous } \\
\text { working } \\
\text { environment }\end{array}$ & $\begin{array}{l}\text { Item } \\
\text { label }\end{array}$ & SWE1 & SWE2 & SWE3 & & & & 0.631 & 0.750 & 0.820 \\
\hline 0.693 & SWE1 & 1 & & & & & 0.78 & & & \\
\hline 0.793 & SWE2 & 0.761 & 1 & & & & 0.88 & & & \\
\hline 0.570 & SWE3 & 0.487 & 0.595 & 1 & & & 0.73 & & & \\
\hline
\end{tabular}

Table 1.

Item analysismeasures of occupational stress
Notes: Key PAS1-PAS4 = poor administrative support; PD1-PD4 = professional distress; Exp1-Exp5 = perceived exploitation; JIS1-JIS3 = job insecurity; WOL1-WOL4 = work overload; IFS1-IFS4 = inadequate financial security; SWE1-SWE3 = strenuous working environment. AVE represents average variance extracted and CR represents composite reliability 
was eliminated from the scale. Further, results presented in Tables 1 and 2 state that the inter-item correlation of all the dimensions are positively correlated except one item from labeled "poor administration support" and "work overload." As a result, these items were eliminated and others were retained for further analysis. The results reveal that all individual items have a positive correlation with the corresponding constructs. The correlation of all the items to a specific latent factor were found above the standard limit of 0.30 , thus indicating that each item contributes significantly to its relevant scale. The Cronbach's alpha of various constructs ranges from 0.75 to 0.91 , which indicates that all the constructs are internally consistent with each other and AVE above 0.50 and CR above 0.70 , indicating convergent validity and internal consistency for the scale. The examination of the Alpha reliability coefficients, inter-correlation, item-total correlation, AVE and CR of the four understudy variables, indicate that the overall measurement scale has sufficient reliability. Therefore, it could be considered valid and reliable.

The DV of the measurement models was established by comparing the AVE with the squared correlation between the three constructs (Fornell and Larcker, 1981). To test this, if the square root of AVE is larger than the correlation coefficients then DV is assumed to be established. From Table 3, it can be seen that all AVEs for the construct are higher than the squared inter-construct correlations and the coefficients of Cronbach's alpha, indicating good validity of the measurement scale. High coefficient of Cronbach's alpha indicates the high level of validity of the measurement scale. This result provides evidence for the achievement of DV.

\section{Sample and data collection procedures}

A simple random sampling technique was used to collect data from the context of a single private sector of school educational institutions in Jammu and Kashmir, India. As the population of this study was unknown, the following formula was used to determine the size of the sample (Krejcie and Morgan, 1970):

$$
\text { Sample Size }=(\text { Range } / 2)^{2} \div(\text { Accuracy level } / \text { confidence level })^{2}
$$

By applying this formula, the sample size arrived at was 620. Based on these, 650 questionnaires were distributed among the private school teachers. About 628 questionnaires were received back out of which 22 were rejected as they were incomplete. Hence, the final sample consists of 628 teachers working in the different private schools of the state. The responses were collected in June/July 2019 from private school teachers through a well-structured questionnaire consisting of 51 statements regarding various aspects of the present study. As this study mainly puts emphasis on the role of labor market conditions and its impact on the psychological well-being of employees at the workplace. Therefore, it was imperative to select the population for the study that has a higher supply in the labor market than its demand. For that matter, private school teachers in the depressed state of Jammu and Kashmir (India) were found suitable for the present investigation. The purification of the instrument resulted in the removal of one item for each of poor administrative system (PAS), work overload (WOL), inadequate financial security (IFS) and normative commitment (NC) statements during the reliability test and CFA. Prior to the final analysis of the data, negatively worded items were reversed and outliers were identified and removed from the final data set. It was observed that 3 respondents were outliers and were subjected to the deletion resulting in the retention of 628 respondents as the final sample size. All the Skewness and Kurtosis values were observed between -1 and 1 and the collected data were found normal to carry out subsequent analysis. 


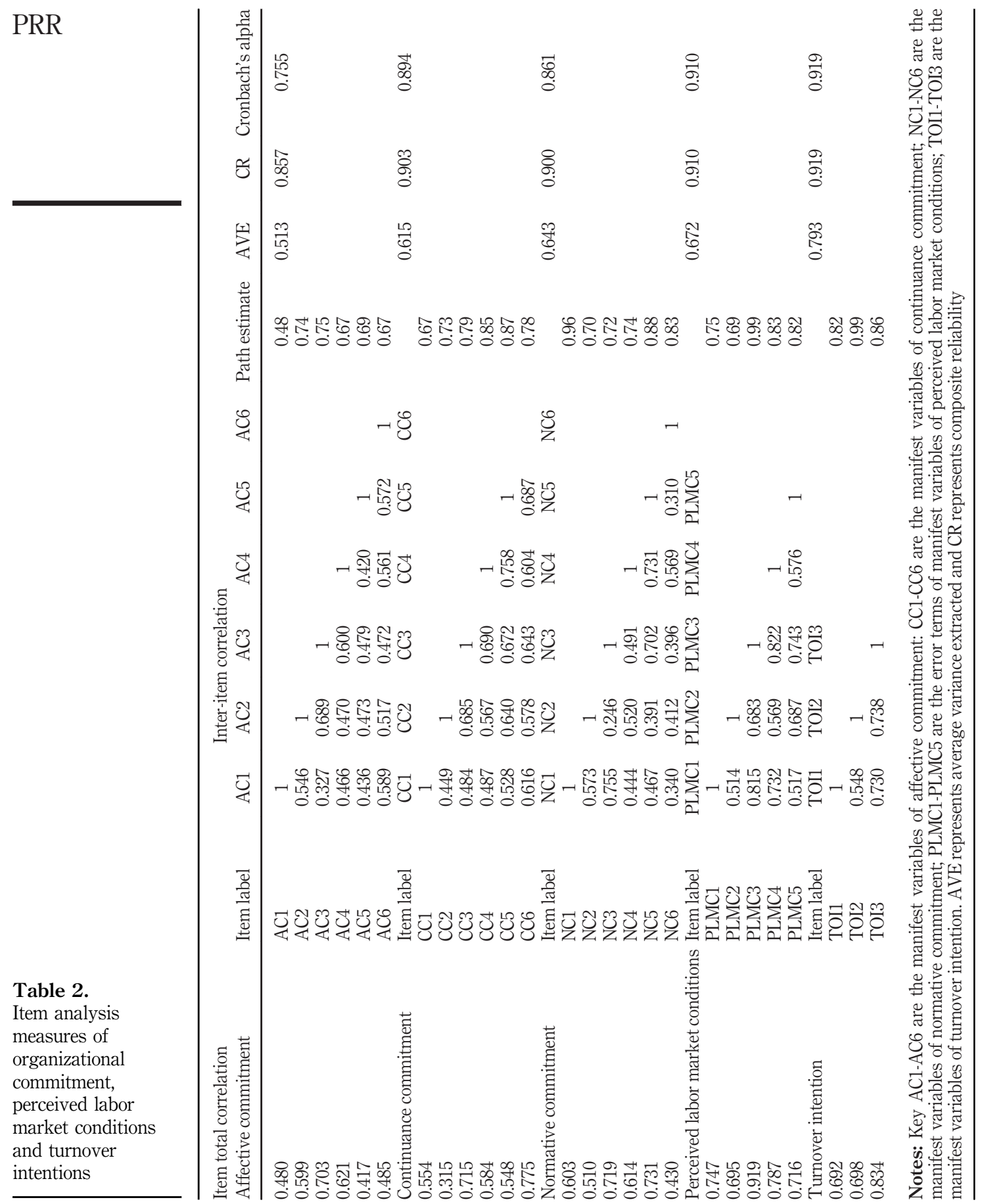




\section{Sample characteristics}

Table 4 exhibits the demographic characteristics of the sample in which $34.81 \%$ of teachers are men and $65.18 \%$ are women. The private school teachers are mostly dominated by women because of their preferences to this job in the Jammu and Kashmir society (Chopra and Gartia, 2009). Further sample results reveal that $57.2 \%$ were married respondents and $42.8 \%$ were unmarried respondents. The experience of $4-6$ years has the highest percentage of respondents (39\%) followed by $1-3$ years $(34.4 \%)$ and the experience above $13-15$ years has the lowest number of respondents $(4.0 \%)$. Moreover, the majority of the respondents having educational qualification of post-graduation with B.Ed degree were $(32.0 \%)$ and the respondents with minimum educational qualification were $(5.7 \%)$.

\section{Common method variance}

As the data collected were self-reporting, which can cause a common method bias problem (Podsakoff et al., 2003). Therefore, to reduce this issue, procedural remedies were undertaken to prevent the inclusion of these prejudices that is to protect the confidentiality of respondents and

\begin{tabular}{lccccc}
\hline Item label & Cronbach's alpha & OS & OC & TOI & PEO \\
\hline OS & 0.864 & 0.633 & & & \\
OC & 0.849 & 0.419 & 0.715 & & \\
TOI & 0.900 & 0.607 & 0.513 & 0.738 & \\
PEO & 0.890 & 0.091 & 0.245 & 0.563 & 0.697
\end{tabular}


to reduce the ambiguity of items. Common method bias is to be examined for all constructs in the study through the common latent factor method (Podsakoff, 2003). The results of the common method variance explained that there is no item, the difference being greater than 0.20 as recommended by Gaskin (2012). Thus, no single major factor emerged to account for the majority of the variances explained by the model, providing preliminary evidence that there is no significant common method bias in the data (Jakobsen and Jensen, 2015).

\section{Confirmatory factor analysis}

CFA is used as a multivariate technique to test whether the pre-specified relationships exist between the manifest and latent variables. It provides a conformity test to our measurement model. It is a way of testing how well-measured variables represent latent constructs (Demirbag et al., 2006). CFA is a statistical method of determining how well our specified factors match reality (the actual data). In this view, CFA is a tool that enables us to either confirm or reject our preconceived theory. The relevance of the constructed measurement model has been assessed with various GFIs: GFI the values of which were above 0.90, meeting the required cut-off criterion, CFI, which were above the acceptable limits of 0.90 , RMSEA is based on the fit between the implied covariance matrix and the estimated population covariance matrix rather than the sample covariance matrix (Byrne, 2001). The smaller this index the better the fit it indicates. Chi-square should be supplemented with the overall fit measures in assessing the validity of the model. It has another name CMIN/DF (minimum discrepancy divided by degree of freedom) ratio, which should be within the recommended range of less than 5 . For the model to be fit, at least one absolute criterion and one incremental fitness criteria should meet the prescribed limits to ensure the valid application of the measurement model (Hair et al., 2006).

\section{Model summary I}

Model summary determines the degree to which the structural model fits sample data. Analysis of moments structure (AMOS) output table yielded a chi-square value of 1,013.16 with 278 degrees of freedom. The CMIN/DF (minimum discrepancy divided by degree of freedom) ratio was 3.64 , which is within the recommended range of less than 5 , which is indicative of the acceptable fit between the hypothetical model and sample data (Carmines and Mclver, 1981).The GFI was 0.927 and CFI was 0.934. CFI exceeds the minimum recommended level of 0.90 and the RMSEA was 0.076 that falls within the cut off limit of 0.08 .

\section{Model summary II}

A three-factor measurement model (Figure 3) was developed to validate the scale. CFA was conducted to test the measurement model and evaluated on three different fit indices, namely, CFI, GFI and RMSEA. The results of CFA indicated that the model fits the data quite well. Chi-square $=321.18$ given that $\mathrm{df}=116$ and CMIN/Df $=2.76$. Specifically, $\mathrm{CFI}$ was found to be 0.962 , GFI was 0.944 and RMSEA was 0.066 .

\section{Model summary III}

The CFA results of the five items indicated that the model was a good fit to the data because the cut-off ranges of fit indices were acceptable as per the recommendation level. CFA analysis suggested that the model was acceptable without any modifications. Chi-square value is 13.5 with 5 degrees of freedom. The CMIN/DF ratio is 2.7 that is well within the 
recommended range of less than 5 and $\mathrm{CFI}=0.981$ and $\mathrm{GFI}=0.971$. The most significant index of model fit indices is RMSEA that is equal to 0.052 . conditions

\section{Model summary IV}

Turnover intention (TOI) consisted of three manifest variables, namely, TOI1. TOI2 and TOI3 (Figure 5). Application of CFA resulted in high standardized regression weights and the model shows excellent model fit indices with chi-square value of 0.000 with zero degree of freedom. The CFA analysis suggests that the model is acceptable without any modification while as GFI is 0.999 , CFI is also 0.999 and (RMSEA) 0.051.

\section{Analysis and results}

The structure equation modeling analysis was used to test the hypotheses in the conceptual model, using regression analyzes. Maximum likelihood approach with 5,000 bootstrapping subsamples similarly adopted by Bhat et al. (2018) was used to test the proposed hypotheses. The structural model includes exogenous latent variables (independent variables), namely, occupational stress, organizational commitment as intervening and turnover intention as endogenous latent variable (dependent variable). Assessing the concordance of the model to the underlying data, the results from the fit indices are shown in Figure 6.

The model starts with seven generic facets of the job, contributing to the formation of occupational stress variable being directly regressed upon employee turnover intentions. The standard estimation of each antecedent of occupational stress was found satisfactory to the minimum criteria of 0.50 in fact these estimations indicate their representation to occupational stress. As can be seen in Figure 6, the path from occupational stress $\rightarrow$ turnover intention has a regression estimate of 0.52 , critical ratio of 9.47 significant at 0.01 and supports $H 1$. Further, the path occupational stress $\rightarrow$ organizational commitment has a regression estimate of -0.64 , critical ratio of 7.47 significant at 0.01 and supports $H 2$. Similarly, the path organizational commitment $\rightarrow$ turnover intention has a regression estimate of -0.37 , critical ratio of 6.78 significant at 0.01 , and thus, supports $H 3$. The coefficient of determination $\left(R^{2}\right)$ depicts that occupational stress and organizational commitment determine $57 \%$ of turnover intention and the rest of $43 \%$ is explained by other variables not undertaken in this study. For testing $H 4$, mediation analysis was performed through bias-corrected percentile bootstrap with $95 \%$ confidence interval to get standardized effects. Mediation results are given in Table 5, which shows total, direct and

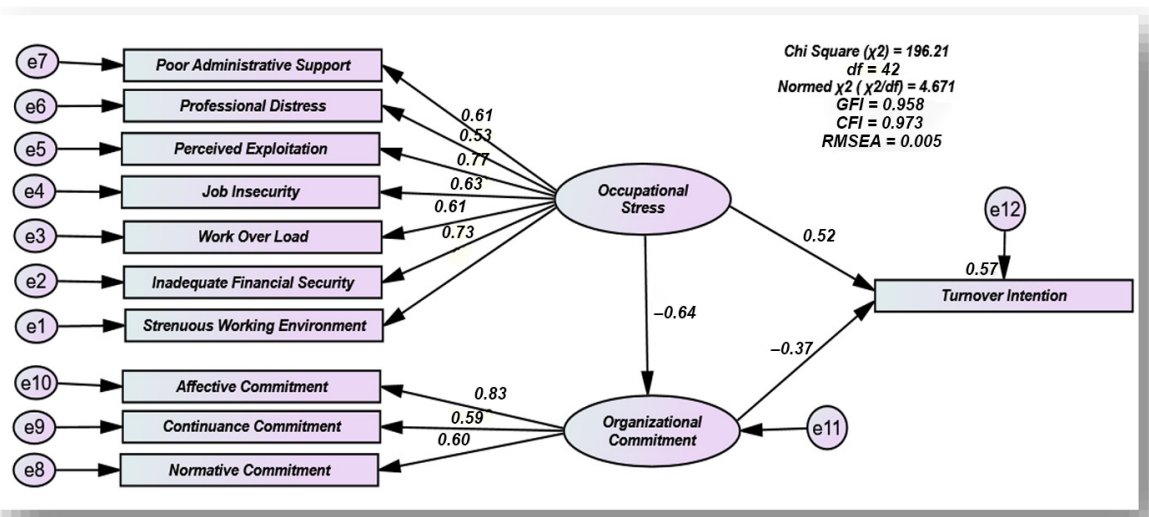

Figures 6. Structural model 


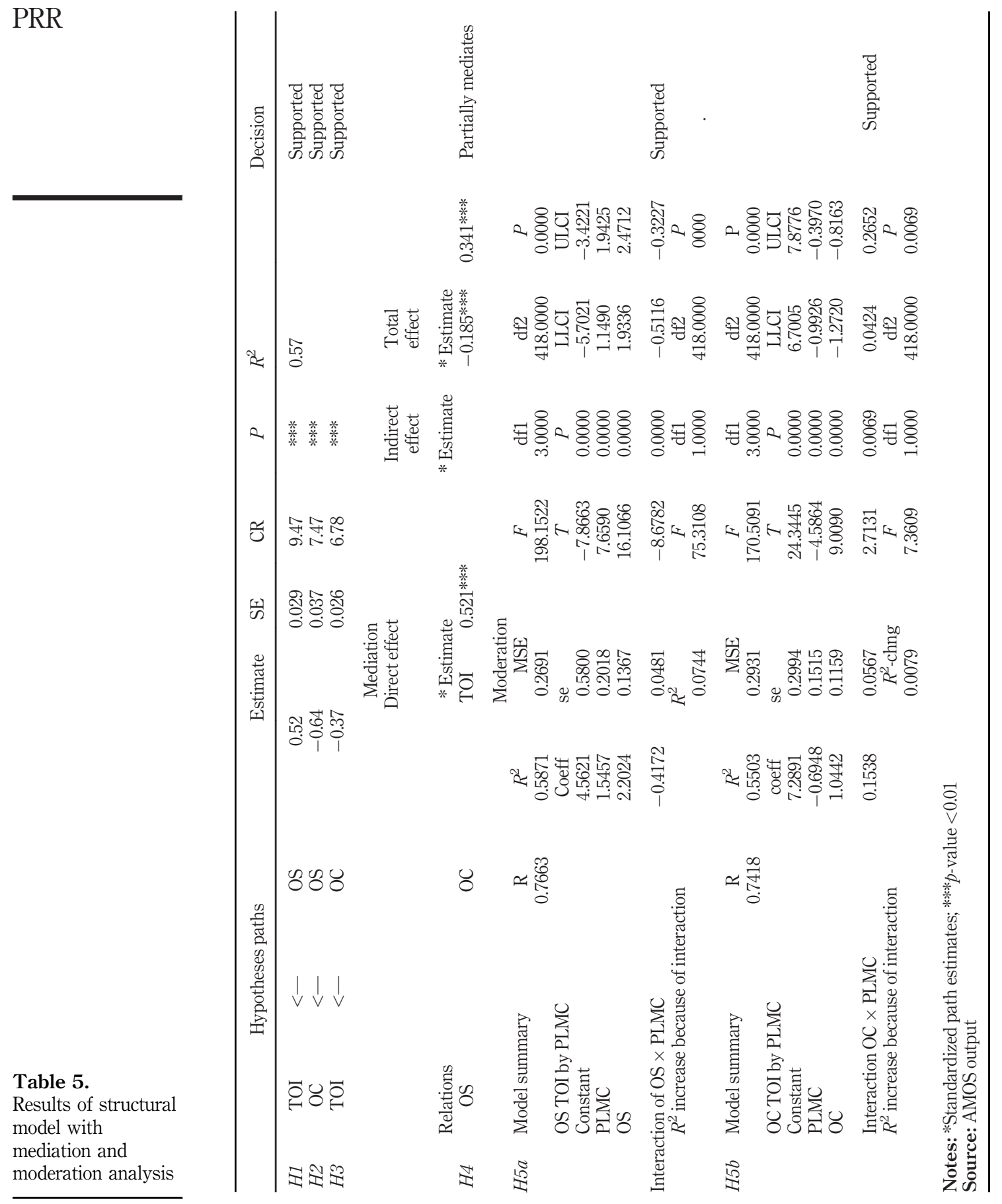


indirect effects. As depicted in this table, the direct relationship between occupational stress and turnover intention is significant $(\phi$-value $=0.000)$, as well as indirect relationship through organizational commitment $(p$-value $=0.000)$. In such cases, Hair et al. $(2010)$ and Kline (2011) have recommended that when both direct and indirect paths are significant, divide standardized indirect effect by standardized total effect, if the outcome is more than $50 \%$, then there is evidence of full mediation and if it is below $50 \%$ then it is treated as partial mediation. Therefore, organizational commitment partially mediates the effect of occupational stress on turnover intention. Thus, $H 4$ is partially accepted.

The moderating role of PLMC in the relationship between occupational stress and employee turnover intentions was examined using statistical package for social science (SPSS) Macro PROCESS by Hayes (2012). To determine the moderating effect, the interaction term of independent variables were created. The standard regression path coefficient indicates a significant impact of occupational stress, labor market conditions and interaction term on the employee turnover intentions. The interaction effects were calculated using 5,000 bootstrapping sample and 95\% confidence level. The results from moderation analysis were further demonstrated using moderating plot diagram. In the regression equation, we included an interaction component (occupational stress multiplied by PLMC). Table 5 presents the results for $H 5 a$ for the moderation hypothesis. As $H 5 a$ stated that the relationship between occupational stress and employee turnover intention will be stronger for those employees' perceived high external opportunities than those perceived low external opportunities. The results indicated that the interaction term between occupational stress multiplied by perceived external opportunities on employee turnover intention was significant $(\beta=-0.4172, t=-8.6782, P=0.000)$. Furthermore, the statistical results demonstrated that the upper bound and lower bound of the confidence interval did not include zero for $H 5 a$, which is depicted in Table 5 to fully support H5a. Further, we applied conventional procedures for plotting simple slopes (Figure 7) at one standard deviation above and below the mean of the perceived external opportunities. The slopes indicate that PLMC moderates the impact of occupational stress on employee turnover intentions. Moreover, the interaction effect of organizational commitment on employees' turnover intentions through PLMC levels as moderator was positive and significant $(\beta=0.1538, t=2.7131, p<0.001)$. This result provided support for $H 5 b$. The statistical results of the SPSS Macro PROCESS demonstrated that the interaction effect of organizational commitment on turnover intention was significant at the moderator value of one standard deviation above the mean and the upper and lower bound of the $95 \%$ bias corrected confidence interval included zero (0.0424 to 0.2652$)$. To further examine

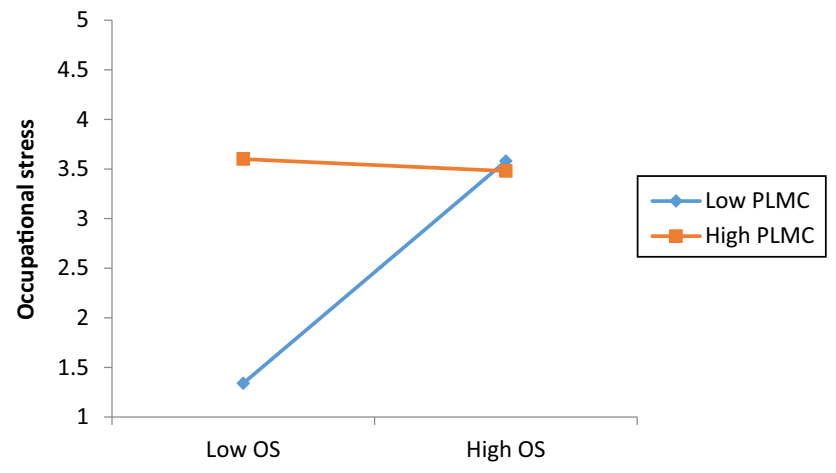

Figure 7. Moderating role of perceived labor market conditions between occupational stress and employee turnover intention

Labor market conditions 
the patterns of interaction, we plotted the interactive effect (Figure 8). Thus, we concluded that the moderated model was supported.

\section{Discussion}

The present study intends to focus broadly on the role of employees' PLMC in the conventional model of employee turnover intentions. This paper incorporates employees' perception toward the labor market in the employees' turnover intention model and investigates how various situations outside work (labor market conditions) play a role in the employee-organizational membership. Furthermore, mediating role of commitment in the relationship between stress and turnover model was also assessed. The results reveal that occupational stress significantly predicts an employee turnover intention that is in line with (Ji-Young and Wang, 2019), who found employees experiencing a high level of stress results in absenteeism and turnover. There are many other researchers who found that the higher experience of stress is, the higher will be employees' turnover intentions (Hoe-Chang et al., 2016). The outcome indicating a negative association between occupational stress and organizational commitment was substantiated with the existing research findings by Saadeh and Suifan (2020). Yet, based on the strength of the relationship, the results reveal that employees' feeling of obligation and organizational membership is relatively less affected by their level of occupational stress. The reason is quite clear as the two extraneous variables i.e. noble nature of teachers' jobs pushes them to strive for their best performance irrespective of negative experience with some aspects of the jobs, while simultaneously lack of external opportunities forces them to continuing their organizational membership. However, the intervention of organizational commitment as a mediator between organizational commitment and turnover intentions results in organizational commitment to restrain employees from actual turnover by developing positive feelings among employees toward their organizations. Moreover, the psychological consequences of unemployment go beyond the pure economic considerations (Winefield, 2002). This study shows that unemployed manifest incidence of stress, anxiety and depression (Bordea $e$ t al., 2014). Unemployed individuals will result in lower psychological well-being at an aggregate level and exert negative spill-over effects. High unemployment rate attenuates the detrimental effects of personal unemployment. Unemployment is the emotionally demanding situation for the employees (Lazarus and Folkman, 1984). Hence, total unemployment as a macroeconomic phenomenon affects the individual perceptions and is strongly related to increased reports of bad self-perceived health. In such a circumstance, the employee stays with no affection, obligation and loyalty toward his employing organization

Figure 8.

Moderating role of perceived labor market conditions between organizational commitment and employee turnover intention

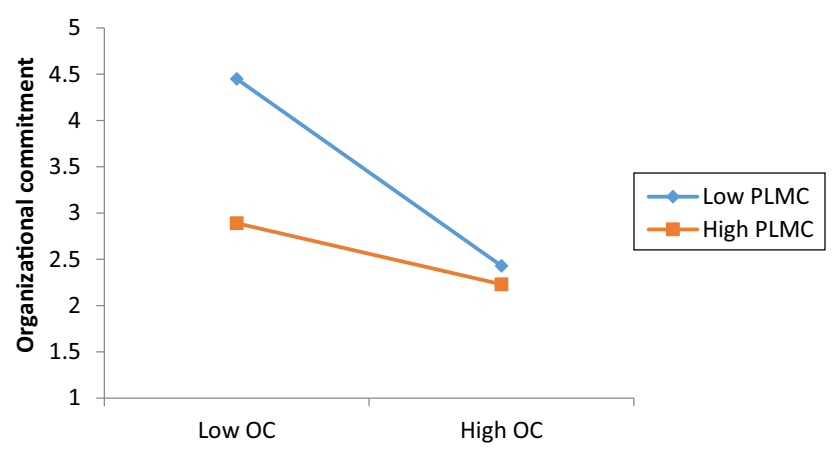


(Chen et al., 2011). Consequently, employers take leverage of adverse economic conditions to exploit their employees for their own cost effectiveness. It further gives rise to labor exploitation, which manifests itself in the undesirable working conditions and "casualization" (Kazeem, 2004).

Furthermore, an undue flow of skilled labor into the labor market compels employees to continue with their organizations even against their desires and demands (Wincent and Örtqvist, 2006). This facilitates employers exploiting human resources toward low input and extensive output. Contrary to the established notions of organizational behavior, the present study revealed that despite the poor human resource management, organizations are able to restrain turnover intentions among their employees. Results reveal that the poor labor market conditions compel employees to maintain their organizational membership. It indicates that the lack of perceived job alternates plays a major role in the employeremployee relationship. True, the employer gets his job done by its employees not by good human resources management but by capitalizing upon the worsening economic conditions, pious nature of school teachers and women dominated industry. In other words, it may be asserted that the subject of human resources management loses its relevance in times of poor labor market conditions.

In fact, microeconomic variables force employees to compromise with the worst quality of work life (Arafat, 2013) and continue with an organization. These compelling forces spur from lack of alternate job opportunities and were labeled as the exogenous factors in the previous studies. These exogenous forces moderate the relationship among the psychological variables. These findings provide empirical attestation to the notion of various researchers such as Carsten and Spector (1987) and Muchinsky and Morrow (1980). Therefore, it is advisable to combine the job searching assistance with psychological assistance for the unemployed youth. As economic development calls for addressing social protection and employment, therefore, formalization of jobs in the informal part of the economy has to be done prudently accent to formalized jobs.

\section{Conclusion}

The study includes employees' perception toward the labor market in the employee turnover intention models. As such, it investigates how employees' perception of the labor market affects their organizational membership and recognizes how various situations outside work (labor market conditions) play a role in the employee-organization relationship. It was found that in spite of severe workplace conditions, an employee feels undecided about his organizational membership mainly due to external economic conditions that force employees to maintain organizational membership. The results revealed that labor market conditions moderate the relationship between occupational stress and employee turnover intentions and subsequently organizational commitment and employee turnover intentions.

Contrary to the orthodox norms of intricacies in the employee turnover intention models, employees were found to feel undecided about their organizational membership in times of severe labor market disequilibrium. As such, external economic conditions force employees to maintain organizational membership irrespective of their severe workplace conditions of work intensification and job insecurity. The results reveal some useful findings in the domain of organizational behavior and human resource management. It was found that in spite of severe workplace conditions of high organizational stress and low organizational commitment, the perceived labor economic conditions compel employees to maintain their organizational membership. Contrary to the conventional norms of relationship that occupational stress is negatively related to organizational commitment and consequently initiates undesirable employees' organizational relationship, such as high turnover 
intentions, the results from moderation analysis revealed that orthodox relationship between organizational stress, organizational commitment and employees' turnover intentions changes in the times of recessive economic conditions of the state.

\section{Practical implications}

This study contributes to academicians and researchers alike. This investigation adds to the prior body of knowledge in organizational behavior literature by evaluating the moderating role of PLMC on employee turnover intentions. The core assumption of the job demand resources model is that resources are likely to buffer unfavorable effects of demands. Alternate employment opportunities has been considered an important tool in increasing employees' control over their working life (Berntson and Marklund, 2006; Silla et al., 2009). However, the findings of this study reveal that employees stay with their organizations even in the severe working conditions. As such, employee-organizational relationship is governed more by the external economic conditions than by employees' psychological feelings toward the organization (organizational commitment). And also, employees' value system, as well as their feelings toward the noble profession, makes them feel spiritually exalted and it confines them to the organizational membership.

\section{Limitations and future research directions}

A single cross-sectional nature of the study remained a major limitation for the present study, and thus, future research studies would take multiple sections to decipher valid conclusions. Further, for the purpose of this study, we assumed that stress is the only predictor of organizational commitment but there are many other potential factors worth studying that demand due consideration. Future research in this context should be continued not only in India but also in other cultures in a longitudinal timeframe. The study provides direction regarding the challenges to the human resource practitioners on how to minimize stressful working conditions and increase employees' commitment. Also, the findings from the study provide guidelines for organizations to sustain their capabilities for providing the competitive edge over others rather than leverage the external job market.

\section{References}

Aaron, C. and Ronit, G. (2007), "Predicting absenteeism and turnover intentions by past absenteeism and work attitudes: an empirical examination of female employees in long term nursing care facilities", Career Development International, Vol. 12 No. 2, pp. 416-432.

Ahmad, A. (2018), "The relationship among job characteristics organizational commitment and employee turnover intentions: a reciprocation perspective", Journal of Work-Applied Management, Vol. 10 No. 1, pp. 74-92.

Ahmad, A. and Rainayee, R.A. (2013), "Exploring a common theme of organizational commitment: a way to consesusness", Pacific Business Review International, Vol. 6 No. 1, pp. 67-68.

Ahmad, R., Islam, T. and Saleem, S. (2019), "How commitment and satisfaction explain leave intention in police force?”, Policing: An International Journal, Vol. 42 No. 2, pp. 195-208.

Anderson, J.C. and Gerbing, D.W. (1988), "Structural equation modeling in practice: a review and recommended two-step approach", Psychological Bulletin, Vol. 103 No. 3, pp. 411-423.

Arnold, H.J. and Feldman, D.C. (1982), "A multivariate analysis of the determinants of job turnover", Journal of Applied Psychology, Vol. 67 No. 3, pp. 350-360.

Aydem, C. (2011), "Investigating occupational commitment and turnover intention relationship with burnout syndrome”, Business and Economics Research Journal, Vol. 2 No. 3, pp. 109-119. 
Bakker, A.B. (2001), "Hoe werkomstandigheden van invloed zijn op burnout: het WEB-model", $C A L$ Hoogduin, WB Schaufeli, CPDR Schaap and AB Bakker (Red.), Behandelingsstrategieën bij burnout, pp. 21-39.

Labor market conditions

Becker, T.E. and Billings, R.S. (1993), "Profiles of commitment: an empirical test", Journal of Organizational Behavior, Vol. 14 No. 2, pp. 177-190.

Bedeian, A.G. and Armenakis, A.A. (1981), "A path-analytic study of the consequences of role conflict and ambiguity", Academy of Management Journal. Academy of Management, Vol. 24 No. 2, pp. 417-424.

Berntson, E. and Marklund, S. (2006), "The relationship between employability and subsequent health”, Paper presented at the Sixth Conference on Psychology and Health, 8-10 May, Kerkrade.

Bhat, A.M. (2013), "Occupational stress among bank employees: an empirical study", International Journal of Scientific Research, Vol. 2 No. 1, pp. 169-170.

Bhat, A.M. (2019), "Occupational stress pessimistic organizational commitment: a psychoeducational perspective", International Journal of Research and Analytical Reviews, special issue, pp. 380-386.

Bhat, S.A., Darzi, M.A. and Parrey, S.H. (2018), "Antecedents of customer loyalty in banking sector: a mediational study", Vikalpa: The Journal for Decision Makers, Vol. 43 No. 2, pp. 92-105.

Biglan, A. and Embry, D.D. (2013), "A framework for intentional cultural change", Journal of Contextual Behavioral Science, Vol. 2 Nos 3/4, pp. 95-104.

Billings, R. and Wemmerus, V. (1983), "The role of alternatives in process models of employee withdrawal", Proceedings of the 26th annual conference of the Midwest Academy of Management, pp. 18-29.

Bordea, E.-N., Pellegrini, A. and Armean, P. (2014), "Evaluation and comparison of the mental level stress in the unemployed persons and the employees in the urban area”, Age 20, p. 65.

Boswell, W.R., Gardner, R.G. and Wang, J. (2017), "Is retention necessarily a win? Outcomes of searching and staying", Journal of Vocational Behavior, Vol. 98, pp. 163-172.

Burchell, B., Ladipo, D. and Wilkinson, F. (2002), Job Insecurity and Work Intensification, Routledge, London.

Carmines, E. and Mclver, J. (1981), Analyzing Models with Unobserved Models: Analysis of Covariance Structures, Beverly Hills.

Carsten, J.M. and Spector, P.E. (1987), "Unemployment, job satisfaction, and employee turnover: a meta-analytic test of the Muchinsky model”, Journal of Applied Psychology, Vol. 72 No. 3, pp. 374-349.

Cartwright, S. and Cooper, C.L. (2002), “ASSET: an organizational stress screening tool”, Management Guide, Robertson Cooper, Manchester, England.

Chahal, H. and Kaur, J. (2014), "Development of marketing capabilities scale in banking sector", Measuring Business Excellence, Vol. 18 No. 4, pp. 65-85.

Chan, S.H.J. and Darian Ao, C.T. (2019), "The mediating effects of job satisfaction and organizational commitment on turnover intention, in the relationships between pay satisfaction and workfamily conflict of casino employees", Journal of Quality Assurance in Hospitality and Tourism, Vol. 20 No. 2, pp. 206-229.

Chen, M.F., Lin, C.P. and Lien, G.Y. (2011), "Modelling job stress as a mediating role in predicting turnover intention", The Service Industries Journal, Vol. 31 No. 8, pp. 1327-1345.

Chiang, C.F. and Liu, B.Z. (2017), "Examining job stress and burnout of hotel room attendants: internal marketing and organizational commitment as moderators", Journal of Human Resources in Hospitality and Tourism, Vol. 16 No. 4, pp. 1-17.

Chopra, R. and Gartia, R. (2009), "Accountability of secondary school teachers in relation to their occupational stress”, EduTracks, Vol. 8 No. 7, pp. 41-43. 
Churchill, G.A. Jr (1979), “A paradigm for developing better measures of marketing constructs”, Journal of Marketing Research, Vol. 16 No. 1, pp. 64-73.

Collins, M., Knutti, R., Arblaster, J., Dufresne, J.L., Fichefet, T., Friedlingstein, P., Gao, X., Gutowski, W. J., Johns, T., Krinner, G. and Shongwe, M. (2013), "Long-term climate change: projections, commitments and irreversibility", Climate Change 2013-The Physical Science Basis: Contribution of Working Group I to the Fifth Assessment Report of the Intergovernmental Panel on Climate Change, Cambridge University, pp. 1029-1136.

Cooper, C.L. (2002), "The changing psychological contract at work", Occupational and Environmental Medicine, Vol. 59 No. 6, p. 355.

Cooke, M., Holzhauser, K., Jones, M., Davis, C. and Finucane, J. (2007), "The effect of aromatherapy massage with music on the stress and anxiety levels of emergency nurses: comparison between summer and winter", Journal of Clinical Nursing, Vol. 16 No. 9, pp. 1695-1703.

Cox, T. (1987), "Stress, coping and problem solving”, Work and Stress, Vol. 1 No. 1, pp. 5-14.

Cummann, C., Fichman, M., Jenkins, D. and Klesh, J. (1979), The MI Organizational Assessment Questionnaire, Unpublished Manuscript, University of MI, Ann Arbor, MI.

Dello Russo, S., Parry, E., Bosak, J., Andresen, M., Apospori, E., Bagdadli, S., Chudzikowski, K., Dickmann, M., Ferencikova, S., Gianecchini, M. and Hall, D.T. (2020), "Still feeling employable with growing age? Exploring the moderating effects of developmental HR practices and country-level unemployment rates in the age - employability relationship", The International Journal of Human Resource Management, Vol. 31 No. 9, pp. 1180-1206.

Demerouti, E., Bakker, A., Nachreiner, F. and Schaufeli, W. (2001), "The job demand resources model of burnout", Journal of Applied Psychology, Vol. 86 No. 3, pp. 499-512.

Demirbag, M., Tatoglu, E., Tekinkus, M. and Zaim, S. (2006), "An analysis of the relationship between TQM implementation and organizational performance: evidence from Turkish SMEs”, Journal of Manufacturing Technology Management.

Fazio, J., Gong, B., Sims, R. and Yurova, Y. (2017), "The role of affective commitment in the relationship between social support and turnover intention", Management Decision, Vol. 55 No. 3, pp. 512-525.

Fishbein, M. and Ajzen, I. (1975), Belief, Attitude, Intention and Behaviour: An Introduction to Theory and Research, Addison-Wesley, Reading, MA.

Fogarty, T.J., Singh, J., Rhoads, G.K. and Moore, R.K. (2000), “Antecedents and consequences of burnout”, Behavioral Research in Accounting, Vol. 12, pp. 31-68.

Fornell, C.G. and Larcker, D.F. (1981), "Evaluating structural equation models with unobservable variables and measurement error", Journal of Marketing Research, Vol. 18 No. 1, pp. 39-50.

Gaskin, J. (2012), “Data screening. Gaskination's StatWiki”, Retrieved March 30, 2015, available at: http://statwiki.kolobkreations.com

Geetha, N., Dhanashree, N. and Mandhanya, Y. (2010), "A study on the causes of work related stress among the college teachers", Pacific Business Review International, pp. 1-7.

Hair, J.F., Black, W.C., Babin, B.J. and Anderson, R.E. (2010), Multivariate Data Analysis, 7th ed., Prentice Hall, Upper Saddle River, NJ.

Hair, J.F., Black, W.C., Babin, B.J., Anderson, R.E. and Tatham, R.L. (2006), Multivariate Data Analysis, 6th ed., Pearson Prentice Hall, Upper Saddle River.

Hakanen, J., Bakker, A. and Demerouti, E. (2005), "How dentists cope with their job demands and stay engaged: the moderating role of job resources", European Journal of Oral Sciences, Vol. 113 No. 6, pp. 479-487.

Han, S.S., Han, J.W., An, Y.S. and Lim, S.H. (2015), "Effects of role stress on nurses' turnover intentions: the mediating effects of organizational commitment and burnout", Japan Journal of Nursing Science, Vol. 12 No. 4, pp. 287-296. 
Haque, A.U. and Aston, J. (2016), "A relationship between occupational stress and organisational commitment of I.T sector's employees in contrasting economies", Polish Journal of Management Studies, Vol. 14 No. 1, pp. 95-105.

Haque, A.U. and Yamoah, F. (2014), “Gender employment longevity: IT staff response to organizational support in Pakistan", International Journal of Academic Research in Business and Social Sciences, Vol. 4 No. 12, pp. 324-347.

Haque, A.U., Aston, J. and Kozlovski, E. (2016), "Do causes and consequences of stress affect genders differently at operational level? Comparison of the IT sectors in the UK and Pakistan", International Journal of Applied Business, Vol. 1 No. 1, pp. 1-7.

Harter, J.K., Schmidt, F.L. and Keyes, C.L. (2002), "Well-being in the workplace and its relationship to business outcomes: a review of the Gallup studies", in Keyes, C.L. and Haidt, J. (Eds), Flourishing: The Positive Person and the Good Life, American Psychological Association, Washington, DC, pp. 205-224.

Hashemi, S.M., Jusoh, J., Kiumarsi, S. and Mohammadi, S. (2015), "Exploring the role of stress on organizational commitment among employees in hospitality industry: the mediating role of job satisfaction”, International Journal of Information Research and Review, Vol. 2 No. 9 , pp. 1144-1150.

Heit, JA., Silverstein, MD., Mohr, DN., Petterson, TM., O’Fallon, WM. and Melton, LJ. (2000), "Risk factors for deep vein thrombosis and pulmonary embolism: a population-based case-control study", Archives of Internal Medicine, Vol. 160 No. 6, pp. 809-815.

Hobfoll, S.E., Halbesleben, J., Neveu, J.P. and Westman, M. (2018), "Conservation of resources in the organizational context: the reality of resources and their consequences", Annual Review of Organizational Psychology and Organizational Behavior, Vol. 5 No. 1, pp. 103-128.

Hoe-Chang, Y., Yoon-Hwang, J. and Lee, Y.C. (2016), "Effects of job stress on self-esteem, job satisfaction, and turnover intention", Journal of Transnational Management, Vol. 21 No. 1, pp. 29-39.

Hom, P.W., Mitchell, T.R., Lee, T.W. and Griffeth, R.W. (2012), "Reviewing employee turnover: focusing on proximal withdrawal states and an expanded criterion", Psychological Bulletin, Vol. 138 No. 5, p. 831.

Horton, B.W. and O'Fallon, M.J. (2011), "Employee wellness in the private club industry", Journal of Human Resources in Hospitality and Tourism, Vol. 10 No. 3, pp. 285-303.

Hossain, S.F., Shan, X., Musa, M. and Rahman, P. (2020c), "Social media and increased venture creation tendency with innovative ideas", in de Pablos, P.O., Zhang, X. and Chui, K.T. (Eds), Handbook of Research on Managerial Practices and Disruptive Innovation in Asia, IGI Global.

Hossain, S.F.A., Nurunnabi, M., Hussain, K. and Shan, X. (2020a), "Smartphone-based m-shopping behavior and innovative entrepreneurial tendency among women in emerging Asia", International Journal of Gender and Entrepreneurship, Vol. 12 No. 2, pp. 173-189, doi: 10.1108/ IJGE-03-2019-0054.

Hossain, S.F.A., Xi, Z., Nurunnabi, M. and Anwar, B. (2019b), "Sustainable academic performance in higher education: a mixed method approach", Interactive Learning Environments, Advance online publication, available at: https://doi.org/10.1080/10494820.2019.1680392

Hossain, S.F.A., Xi, Z., Nurunnabi, M. and Hussain, K. (2020b), Ubiquitous Role of Social Networking in Driving M-Commerce: Evaluating the Use of Mobile Phones for Online Shopping and Payment in the Context of Trust, SAGE Open.

Hossain, S.F.A., Nurunnabi, M., Hussain, K., Saha, S.K. and Wang, S. (2019a), "Effects of varietyseeking intention by mobile phone usage on university students' academic performance", Cogent Education, Vol. 6 No. 1, p. 1574692.

Huang, S.S., Veen, R.V.D. and Song, Z.C. (2018), "The impact of coping strategies on occupational stress and turnover intentions among hotel employee", J. Hosp. Mark. Manag, Vol. 27, pp. 926-945. 
Hurrell, J.J., Jr and McLaney, M.A. (1988), "Exposure to job stress: a new psychometric instrument”, Scandinavian Journal of Work Environment and Health, Vol. 14, pp. 27-28.

Jakobsen, M. and Jensen, R. (2015), “Common method bias in public management studies”, International Public Management Journal, Vol. 18 No. 1, pp. 3-30.

Ji-Young, A. and Wang, C. (2019), "Job stress and turnover intention revisited: evidence from Korean firms", Problems and Perspectives in Management, Vol. 17 No. 4, pp. 52-61.

Kafashpoor, A., Sadeghian, S., Shakori, N. and Kavoosi, S. (2014), "The impact of job stress on turnover intention mediating role of job satisfaction and affective commitment; case study: Mashhad's public hospitals", Applied Mathematics in Engineering, Management, and Technology, Vol. 2 No. 1, pp. 96-102.

Karatepe, O.M., Yavas, U., Babakus, E. and Deitzc, G.D. (2018), "The effects of organizational and personal resources on stress, engagement, and job outcomes", International Journal of Hospitality Management, Vol. 74, pp. 147-161.

Karrasch, A. (2003), "Antecedents and consequences of organizational commitment", Military Psychology - Psychology, Vol. 15 No. 3, pp. 225-236, doi: 10.1207/S15327876MP1503_05.

Kazeem, M. (2004), Functioning of the Nigeria Labour Market, Wiley, New York.

Khuong, M.N. and Nhu, N.V.Q. (2015), "The effects of ethical leadership and organizational culture towards employee's sociability and commitment. A study of tourism sector in Ho Chi Minh City, Vietnam", Journal of Advanced Management Sciences, Vol. 3 No. 4, pp. 329-336.

Kim, H. and Lee, S.Y. (2009), "Supervisory communication, burnout, and turnover intention among social workers in health care settings", Social Work in Health Care, Vol. 48 No. 4, pp. 364-385.

Kim, H. and Stoner, M. (2008), "Burnout and turnover intention among social workers: effects of role stress, job autonomy and social support", Administration in Social Work, Vol. 32 No. 3 , pp. 5-25.

Kim, S.M., Um, K.H., Kim, H.Y. and Kim, Y.H. (2016), "Hospital career management systems and their effects on the psychological state and career attitudes of nurses", Service Business, Vol. 10 No. 1, pp. 87-112.

Kline, R.B. (2011), Principles and Practice of Structural Equation Modeling, 3rd ed., Guilford Press, New York, NY.

Krejcie, R.V. and Morgan, D.W. (1970), "Determining sample size for research activities", Educational and Psychological Measurement, Vol. 30 No. 3, pp. 607-610.

Kumar, R., Ramendran, C. and Yacob, P. (2012), "A study on turnover intention in fast food industry: employees' fit to the organizational culture and the important of their commitment", International Journal of Academic Research in Business and Social Sciences, Vol. 2 No. 5, pp. 9-42.

Kyriacou, C. and Sutcliffe, J. (1977), “Teacher stress: a review”, Educational Review, Vol. 29 No. 4, pp. 299-306.

Lazarus, R.S., and Folkman, S. (1984), Stress, Appraisal, and Coping, Springer publishing company.

Lewchuk, W., de Wolff, A., King, A. and Polanyi, M. (2005), "Beyond job strain: employment strain and the health effects of precarious employment. Work in a global society", Working Paper Series, 2005-1. Labour Studies Programme, Mc Master University.

Lu, L., Guo, X. and Zhao, J. (2017), "A unified nonlocal strain gradient model for nanobeams and the importance of higher order terms", International Journal of Engineering Science, Vol. 119, pp. 265-277.

Magnano, P., Paolillo, A., Platania, S. and Santisi, G. (2017), "Courage as a potential mediator between personality and coping”, Personality and Individual Differences, Vol. 111, pp. 13-18.

Malhotra, N.K. and Dash, S. (2011), Marketing research: an applied orientation, pp. 552-582.

Manier, A.O., Kelloway, E.K. and Francis, L. (2017), "Damaging the workplace: consequences for people and organizations", in Bowling, N.A. and Hershcovis, M.S. (Eds), Research and Theory on Workplace Aggression, Cambridge University Press, pp. 62-92. 
Mano-Negrin, M.R. and Tzafrir, S.S. (2004), "Job search modes and turnover", Career Development International, Vol. 9 No. 5, pp. 442-446.

Marique, G. and Stinglhamber, F. (2011), "Identification to proximal targets and affective organizational commitment: the mediating role of organizational identification", Journal of Personnel Psychology, Vol. 10 No. 3, pp. 107-117.

Meer, P. (2014), "Gender, unemployment and subjective well-being: why being unemployed is worse for men than for women", Social Indicators Research, Vol. 115, pp. 23-44.

Menon, P.P. and Priya, V. (2019), "Impact of market economic principles on workplace anxiety and stress", Indian Journal of Public Health Research and Development, Vol. 10 No. 9, pp. $145-150$.

Mercurio, Z.A. (2015), "Affective commitment as a core essence of organizational commitment”, Human Resource Development Review, Vol. 14 No. 4, pp. 389-414.

Mérida-López, S. and Extremera, N. (2017), "Emotional intelligence and teacher burnout: a systematic review”, International Journal of Educational Research, Vol. 85, pp. 121-130.

Meyer, J.P. and Allen, N.J. (1991), "A three-component conceptualization of organizational commitment”, Human Resource Management Review, Vol. 1 No. 1, pp. 61-89.

Meyer, J.P. and Allen, N.J. (1997), Commitment in the Workplace: Theory, Research, and Application, Sage.

Meyer, J.P. and Herscovitch, L. (2001), "Commitment in the workplace: toward a general model", Human Resource Management Review, Vol. 11 No. 3, pp. 299-326.

Meyer, J.P., Stanley, D.J., Herscovitch, L. and Topolnytsky, L. (2002), "Affective, continuance, and normative commitment to the organization: a meta-analysis of antecedents, correlates, and consequences”, Journal of Vocational Behavior, Vol. 61 No. 1, pp. 20-52.

Michaels, C.E. and Spector, P.E. (1982), "Causes of employee turnover: a test of the Mobley, Griffeth hand, and Meglino model", Journal of Applied Psychology, Vol. 67 No. 1, pp. 53-59.

Mikkelsen, A., Ogaard, T. and Lovrich, N. (2000), "Modeling the effects of organizational setting and individual coping style on employees subjective health, job satisfaction and commitment", Public Administration Quarterly, Vol. 24 No. 3, pp. 371-397.

Montani, F., Courcy, F. and Vandenberghe, C. (2017), "Innovating under stress: the role of commitment and leader-member exchange", Journal of Business Research, Vol. 77, pp. 1-13.

Mosadeghrad, A.M. (2013), "Occupational stress and turnover intention: implications for nursing management", International Journal of Health Policy and Management, Vol. 1 No. 2, pp. 179-186.

Mowday, R.T., Koberg, C.S. and MacArthur, A.W. (1984), "The psychology of the withdrawal process: a cross-validation test of Mobley's intermediate linkages of model turnover in two samples", Academy of Management Journal, Vol. 27, pp. 79-94.

Muchinsky, PM. and Morrow, P.C. (1980), "A multidisciplinary model of voluntary employee turnover", Journal of Vocational Behavior, Vol. 17 No. 3, pp. 263-290.

Mulki, J.P., Jaramillo, J.F. and Locander, W.B. (2008), "Effect of ethical climate on turnover intention: linking attitudinal and stress theory", Journal of Business Ethics, Vol. 78 No. 4, pp. 559-574.

Nair, P. and Kamalanabhan, T.J. (2010), "The impact of cynicism on ethical intentions of Indian managers: the moderating role of their level of management", International Journal of Trade, Economics and Finance, Vol. 1 No. 2, pp. 155-159.

Netmeyer, R.G., Bearder, W.O. and Sharma, S. (2003), Scaling Procedures: Issues and Applications, Sage Publication, London.

Nilufer, S. (2019), "The mediating role of organizational commitment in the effect of job stress on turnover intention", Business and Economics Research Journal, Vol. 10 No. 4, pp. 915-928.

Nissly, J., Mor Barak, M. and Levin, A. (2005), "Stress, social support, and workers' intentions to leave their jobs in public child welfare", Administration in Social Work, Vol. 29 No. 1, pp. 79-100, doi: 10.1300/J147v29n01_06. 
Nixon, A.E., Mazzola, J.J., Bauer, J., Krueger, J.R. and Spector, P.E. (2011), “Can work make you sick? A meta-analysis of the relationships between job stressors and physical symptoms", Work and Stress, Vol. 25 No. 1, pp. 1-22.

Nunnally, J.C. and Bernstein, I.H. (1994), Psychometric Theory, 3rd ed., McGraw-Hill, New York, NY.

O'Driscoll, M.P. and Beehr, T.A. (1994), "Supervisor behaviors, role stressors and uncertainty as predictors of personal outcomes for subordinates", Journal of Organizational Behavior, Vol. 15 No. 2, pp. 141-155.

Okafor, E.E. (2007), "Globalisation, casualisation and capitalist business ethics: a critical overview of situation in the oil and gas sector in Nigeria", Journal of Social Sciences, Vol. 15 No. 2, pp. 169-179.

Onyishi, I.E., Ucho, A. and Mkavga, T. (2012), "Job satisfaction, gender, tenure, and turnover intention among civil servants in Benue state", Interdisciplinary J. Contemp. Res. Bus, Vol. 3 No. 11, pp. 213-226.

Podsakoff, P.M., MacKenzie, S.B., Lee, J.Y. and Podsakoff, N.P. (2003), "Common method biases in behavioral research: a critical review of the literature and recommended remedies", Journal of Applied Psychology, Vol. 88 No. 5, pp. 879-903.

Price, J.L. (2001), "Reflections on the determinants of voluntary turnover", International Journal of Manpower.

Ramamoorthy, N. and Flood, P.C. (2004), "Gender and employee attitudes: the role of organizational justice perceptions", British Journal of Management, Vol. 15 No. 3, pp. 247-258.

Robinson, A.M. (2018), "Let's talk about stress: history of stress research", Review of General Psychology, Vol. 22 No. 3, pp. 334-342.

Rousseau, D.M. (2004), "Psychological contracts in the workplace: understanding the ties that motivate", Academy of Management Perspectives, Vol. 18 No. 1, pp. 120-127.

Saadeh, I.M. and Suifan, T.S. (2020), "Job stress and organizational commitment in hospitals: the mediating role of perceived organizational support”, International Journal of Organizational Analysis, Vol. 28 No. 1, pp. 226-242.

Saxe, R. and Barton, A.W. (1982), "The SOCO scale: a measure of the customer orientation of salespeople", Journal of Marketing Research, Vol. 19 No. 3, pp. 343-351.

Schmidt, S. (2007), "The relationship between satisfaction with workplace training and overall job satisfaction”, Human Resource Development Quarterly, Vol. 18 No. 4, pp. 481-498.

Silla, I., de Cuyper, N., Gracia, F.J., Peiró, J.M. and de Witte, H. (2009), "Job insecurity and well-being: moderation by employability", Journal of Happiness Studies, Vol. 10 No. 6, pp. 739-751.

Smith, J.A., Flower, P. and Larkin, M. (2009), "Interpretative phenomenological analysis: theory method and research".

Snape, E. and Redman, T. (2003), "An evaluation of a three-component model of occupational commitment: dimensionality and consequences among United Kingdom human resource management specialists", Journal of Applied Psychology, Vol. 88 No. 1, pp. 152-159.

Srivastava, A.K. and Singh, A.P. (1984), Occupational Stress Index, Manovaigyanik Parikshan Sansthan, Varanasi.

Stephen, P.R. and Timothy, A.J. (2007), Organizational Behavior, Pearson/Prentice Hall.

Tetteh, S., Wu, C., Sungu, L.J., Opata, C.N. and Agyapong, G.N.Y.A. (2019), "Relative impact of differences in job security on performance among local government employees: the moderation of affective commitments", Journal of Psychology in Africa, Vol. 29 No. 5, pp. 413-420, doi: 10.1080/14330237.2019.1675980.

Tiyce, M., Hing, N., Cairncross, G. and Breen, H. (2013), "Employee stress and stressors in gambling and hospitality workplaces", Journal of Human Resources in Hospitality and Tourism, Vol. 12 No. 2, pp. 126-154. 
Towers Watson Survey (2014), "Indian employers rank stress as \#1 lifestyle risk factor: towers Watson report”, available at: www.towerswatson.com/en-IN/Press/2014/05/Indian-employers-rankstress-as-1-lifestyle-risk-factor

Labor market conditions

Van der Westhuizen, N. (2014), "Turnover intention and employee engagement: exploring eliciting factors in South African audit firms", Doctoral dissertation, Stellenbosch University, Stellenbosch.

Waters, L. (2000), "Coping with unemployment: a literature review and presentation of a new model", International Journal of Management Reviews, Vol. 2 No. 2, pp. 169-182.

Williams, S. and Cooper, C.L. (1998), "Measuring occupational stress: development of the pressure management indicator", Journal of Occupational Health Psychology, Vol. 3 No. 4, pp. 306-321.

Wincent, J. and Örtqvist, D. (2006), "Analyzing the structure of entrepreneur role stress", Journal of Business and Entrepreneurship, Vol. 18 No. 2, p. 1.

Zimmerman, R.D., Swider, B.W., Woo, S.E. and Allen, D.G. (2016), "Who withdraws? Psychological individual differences and employee withdrawal behaviors", Journal of Applied Psychology, Vol. 101 No. 4, pp. 498-519.

\section{Further reading}

Arfat, R. (2013), "Organization, job, perks and employee turnover intentions”, International Monthly Refereed Journal of Research in Management and Technology, Vol. 12, pp. 17-21.

Borman, G.D. and Dowling, N.M. (2008), “Teacher attrition and retention: a meta-analytic and narrative review of the research", Review of Educational Research, Vol. 78 No. 3, pp. 367-411.

Boudrias, J.S., Rousseau, V. and Lajoie, D. (2020), "How lack of integrity and tyrannical leadership of managers influence employee improvement-oriented behaviors", Journal of Business Ethics, pp. 1-16.

Boyas, J., Wind, L.H. and Kang, S.Y. (2012), "Exploring the relationship between employment-based social capital, job stress, burnout and intent to leave among child protection workers: an agebased path analysis model", Children and Youth Services Review, Vol. 34 No. 1, pp. 50-62.

Chan, W.Y., Lau, S., Nie, S.L.Y., Lim, S. and Hogan, D. (2008), "Organizational and personal predictors of teacher commitment: the mediating role of teacher efficacy and identification with school", American Educational Research Journal, Vol. 45 No. 3, pp. 597-630.

Chui, W. (2005), "Understanding hospital employee job stress and turnover intentions in a practical setting: the moderating role of locus of control", Journal of Management Development, Vol. 24, pp. 837-855.

Conley, S. and You, S. (2009), "Teacher role stress, satisfaction, commitment, and intentions to leave: a structural model”, Psychological Reports, Vol. 105 No. 3, pp. 771-786.

Cropanzano, R., Rupp, D.E. and Byrne, Z.S. (2003), "The relationship of emotional exhaustion to work attitudes, job performance, and organizational citizenship behaviors", Journal of Applied Psychology, Vol. 88 No. 1, pp. 160-169.

Dixit, V. and Bhati, M. (2012), "A study about employee commitment and its impact on sustained productivity in Indian auto-component industry", European Journal of Business and Social Sciences, Vol. 1 No. 6, pp. $34-51$.

Firth, L., Mellor, D., Moore, K. and Loquet, C. (2004), "How can managers reduce employee intention to quit?”, Journal of Managerial Psychology, Vol. 19 No. 2, pp. 170-187.

Garg, S. and Dhar, R. (2014), "Effects of stress, LMX and perceived organizational support on service quality: mediating effects of organizational commitment", Journal of Hospitality and Tourism Management, Vol. 21, pp. 64-75.

Guarino, C.M., Santibanez, L. and Daley, G.A. (2006), "Teacher recruitment and retention: a review of the recent empirical literature", Review of Educational Research, Vol. 76 No. 2, pp. 173-208.

Hair, J.F., Black, W.C., Babin, B.J. and Anderson, R.E. (2009), Multivariate Data Analysis, Prentice Hall, Upper Saddle River, NJ. 
Hom, P.W., Lee, T.W., Shaw, J.D. and Hausknecht, J.P. (2017), “One hundred years of employee turnover theory and research”, Journal of Applied Psychology, Vol. 102 No. 3, pp. 530-545.

Jon, C. (2008), "An empirical investigation of the influence of age, gender, and occupational level on stress perceptions, job satisfaction, organizational commitment, and turnover”, Proquest J, pp. 421-431.

Kavanagh, J.E. (2005), "Stress and performance: A review of the literature and its applicability to the military", Technical Report, Retrieved on December 10, 2010.

Khan, M., Ali, N., Ur Rehman, S. and Ahmad, S. (2017), "Mediating role of organizational commitment between occupational stress and turnover intention in Pakistani universities", Sarhad Journal of Management Sciences, Vol. 3 No. 2, pp. 250-260.

Kim, B.C., Murrmann, S.K. and Lee, G. (2009), "Moderating effects of gender and organizational level between role stress and job satisfaction among hotel employees", International Journal of Hospitality Management, Vol. 28 No. 4, pp. 612-619.

Kobasa, S.C. (1998), “Commitment and coping strategies in stress resistance among lawyers”, Journal of Personality and Social Psychology, Vol. 42 No. 4, pp. 707-717, Antrosrusky.

Lofquist, L.H. and Dawis, R.V. (1969), Adjustment to Work: A Psychological View of Man's Problems in a Work-Oriented Society, Appleton-Century-Crofts, New York, NY.

Malhotra, N.K. and Dash, S. (2010), Marketing Research: An Applied Approach, Dorling Kindersely, Pearson Education South Asia.

Malhotra, N.K. and Dash, S. (2016), Marketing Research: An Applied Orientation, Pearson.

Meyer, J.P. and Allen, N.J. (1984), “Testing the 'side-bet theory' of organizational commitment: some methodological considerations", Journal of Applied Psychology, Vol. 69 No. 3, p. 372.

Mobley, W.H. (1982), Employee Turnover: Causes. Consequences, and Control, Addison-Wesley Publishing, Philippines.

Noordin, N.F.M., Panatik, S.A.B., Rajab, A., Shaari, R., Saat, M.M. and Wahab, S.A. (2012), "Psychosocial work condition and work attitudes: testing of the effort-reward imbalance model in Malaysia", Procedia - Social and Behavioral Sciences, Vol. 40, pp. 591-595.

Ordóñez de Pablos, P., Zhang, X. and Chui, K.T. (2019), Handbook of Research on Managerial Practices and Disruptive Innovation in Asia, IGI Global, doi: 10.4018/978-1-7998-0357-7.ch011.

Pineau Stam, L.M., Spence Laschinger, H.K., Regan, S. and Wong, C.A. (2015), "The influence of personal and workplace resources on new graduate nurses' job satisfaction”, Journal of Nursing Management, Vol. 23 No. 2, pp. 190-199.

Rousseau, D.M. (1985), "Issues of level in organizational research: multi-level and cross-level perspectives", Research in Organizational Behaviour, Vol. 7, pp. 1-37.

Tett, R.P. and Meyer, J.P. (1993), "Job satisfaction, organizational commitment, turnover intention, and turnover: path analyses based on meta-analytic findings", Personnel Psychology, Vol. 46 No. 2, pp. 259-293.

Vijaya, T.G. and Hemamalini, R. (2012), "Role ambiguity, role conflict and work role balance: influence on organizational commitment and turnover intension of faculty", European Journal of Social Sciences, Vol. 30 No. 4, pp. 574-585. 
Appendix

Occupational stress

Poor administrative support.

PAS1. School authorities are not willing to accept my opinions.

PAS2. Task distribution is not uniform and reasonable.

PAS3. I lack recognition for the extra classes/good teaching I do.

PAS4. Principal is often unaware of the problem faced by a teacher in the classroom work.

PAS5. There is a lack of communication between teachers and school management.

\section{Professional distress.}

PD1. School management demands much more from its faculty, irrespective of facilities provided by the school.

PD2. It is quite difficult to complete the syllabus within the stipulated time.

PD3. Given the vulnerable behavior of students in class, it is difficult for me to deliver my best lecture.

PD4. School-related issues are to be completed at home.

\section{Perceived exploitation:}

EXP1.My qualification is exploited as I am being paid low than I deserve.

EXP2. My present job is compulsion rather than my desire.

EXP3. Given the amount of salary, I feel a sense of exploitation due to unemployment.

EXP4. I cannot demand high pay, for the reason of the threat of losing my job.

EXP5. My job restrains me to meet my desired goals.

\section{Job insecurity.}

JIS1. I feel uncertain about the future of my job in the school.

JIS2. My job is insecure in this school.

JIS3. The school I work for does not provide me a lot of job security.

\section{Work overload}

WOL1. I have to work consecutively for longer working classes.

WOL2. I have to deliver the classes of other teachers in their absence.

WOL3.There is an excessive workload on the one hand and an insufficient number of resources on the other.

WOL4. I have to prepare for number of classes within a short period of time.

WOL5.Being too busy with official work I am not able to devote sufficient time to my domestic and personal problems.

\section{Inadequate financial security.}

IFS1. My salary does not commensurate with the amount of classes I conduct.

IFS2. I earn less than the people working on similar jobs like government.

IFS3. My salary does not meet my requirements/needs.

IFS4. My salary is not paid on time.

\section{Strenuous working environment.}

SWE1. Higher surveillance/monitoring at school frustrates me.

SWE2. Unreasonable management interruption during the class lectures irritates me.

SWE3. I have been provided with an ideal and favorable teaching environment.

\section{Organizational commitment}

Affective commitment.

AC1. I am happy to spend the rest of my career working for this school.

AC2. This school inspires me to perform my job to the best of my ability.

AC3. I am emotionally attached with this school and its management. 
AC4. I really feel as if this institution's (i. e., managements) problems are my own.

AC5. I could easily get attached/adjusted to any other organization as I am attached to this one. the same.

AC6. When it comes to work, I feel my personal values and the thinking of this organization are

\section{Normative commitment.}

$\mathrm{NC1}$. Given the amount of benefits, I derive from this school; I feel it deserves my loyalty.

NC2. I feel a sense of obligation toward this school.

NC3. If I get a better job offer elsewhere I would leave this school.

NC4. I would feel guilty if I leave this school and work elsewhere.

NC5. Unless equally rewarded I feel no reason to put an extra effort in this school.

NC6. I would prefer to leave this school when I feel it is advantageous to me and my family.

\section{Continuance commitment.}

$\mathrm{CC} 1$. One of the serious consequences of leaving this organization would be the scarcity/nonavailability of jobs.

CC2. Right now staying with this school is a matter of necessity.

CC3. It may have a good future if I continue to work for this school.

$\mathrm{CC} 4$. It would be very difficult for me to leave my institution right now, even if I want to.

CC5. One of the major reasons I continue to work for this school is that leaving would require considerable sacrifices. Another organization may not match the overall benefits I have in this school.

CC6. Keeping in view staff relationships, it would not be easy for me to work at other institution/organizations.

\section{Perceived labor market conditions:}

PEO1. I am getting better offers from other institutions to work at higher salary.

PEO2. If I leave this job, I would have another job as good as this one within a short period of time.

PEO3. Given the flow of candidates having qualifications equal to mine, indicate your chance of getting a suitable position in a government organization.

PEO4. Given the economic condition and job policies of J\&K state, it would not be easy to find acceptable alternates employment.

PEO5. Given the Nepotism and corruption in J and K, I am doubtful of getting a job matching my desired qualification.

\section{Turnover intentions.}

TOI1. I will definitely look for another job in the next year.

TOI2. I often think about quitting.

TOI3. I will explore opportunities to find a new job.

\section{Corresponding author}

Mohd Abass Bhat can be contacted at: abass.ashoor.bhat788@gmail.com

For instructions on how to order reprints of this article, please visit our website: 